\title{
The Use of Psychoacoustics in Marine Mammal Conservation in the United States: From Science to Management and Policy
}

\author{
Shane Guan ${ }^{1, *(\mathbb{D})}$ and Tiffini Brookens ${ }^{2, *}$ \\ 1 Department of Mechanical Engineering, The Catholic University of America, Washington, DC 20064, USA \\ 2 U.S. Marine Mammal Commission, Bethesda, MD 20814, USA \\ * Correspondence: guan@cua.edu (S.G.); tbrookens@mmc.gov (T.B.)
}

check for updates

Citation: Guan, S.; Brookens, T. The Use of Psychoacoustics in Marine

Mammal Conservation in the United States: From Science to Management and Policy. J. Mar. Sci. Eng. 2021, 9,

507. https://doi.org/

10.3390/jmse9050507

Academic Editor: Giuseppa Buscaino

Received: 2 April 2021

Accepted: 5 May 2021

Published: 8 May 2021

Publisher's Note: MDPI stays neutral with regard to jurisdictional claims in published maps and institutional affiliations.

Copyright: (c) 2021 by the authors. Licensee MDPI, Basel, Switzerland. This article is an open access article distributed under the terms and conditions of the Creative Commons Attribution (CC BY) license (https:// creativecommons.org/licenses/by/ $4.0 /)$.

\begin{abstract}
Underwater sound generated from human activities has been long recognized to cause adverse effects on marine mammals, ranging from auditory masking to behavioral disturbance to hearing impairment. In certain instances, underwater sound has led to physical injuries and mortalities. Research efforts to assess these impacts began approximately four decades ago with behavioral observations of large whales exposed to seismic surveys and rapidly progressed into the diverse field that today includes studies of behavioral, auditory, and physiological responses of marine mammals exposed to anthropogenic sound. Findings from those studies have informed the manner in which impact assessments have been and currently are conducted by regulatory agencies in the United States. They also have led to additional questions and identified information needed to understand more holistically the impacts of underwater sound, such as population- and specieslevel effects, long-term, chronic, and cumulative effects, and effects on taxa for which little or no information is known. Despite progress, the regulatory community has been slow to incorporate the best available science in marine mammal management and policy and often has relied on outdated and overly simplified methods in its impact assessments. To implement conservation measures effectively, regulatory agencies must be willing to adapt their regulatory scheme to ensure that the best available scientific information is incorporated accordingly.
\end{abstract}

Keywords: underwater sound impacts; marine mammal conservation; impact assessment; behavioral disturbance; hearing impairment; auditory masking

\section{Introduction}

Since the Industrial Revolution, with the mechanization and expansion of human activities into the sea, humans have been introducing pervasive anthropogenic sound into the marine environment [1]. Given that many marine species rely on acoustic cues for their life functions, such as communication, sensing the environment, migration, and detecting predators and prey, elevated anthropogenic sound can have detrimental effects on them [2,3]. To address these concerns and to provide sound scientific information for the conservation of marine mammal species, interdisciplinary studies have been conducted over the past four decades to support impact assessments by various regulatory entities [4,5].

Those assessments typically follow the source-path-receiver model, where the "source" is the anthropogenic sound source, "path" is the underwater sound propagation, and "receiver" is the marine mammal that is exposed to the sound [6]. The former two aspects lie within the field of underwater acoustics, while the latter is addressed in animal bioand psychoacoustics. An overview of the application of underwater acoustics in marine conservation, which focuses on knowledge gained regarding anthropogenic sound sources and sound propagation relevant to impact assessments is discussed in a companion review paper [7]. Here, we provide a review of the application of psychoacoustics in marine mammal impact assessments that support management and policy in the United States. 


\section{An Early History of Research Involving the Effects of Sound on Marine Mammals and Its Application in Impact Assessments: Up to 2000}

The invention of an underwater acoustic transducer to aid navigation and to engage anti-submarine warfare at the turn of the 20th century opened a new field of research in underwater acoustics $[8,9]$. However, it was not until almost half a century later that researchers first documented underwater sound production and communication by marine mammals [10-13]. In the early 1970s, a group of researchers began to recognize the potential adverse effects of anthropogenic sound on marine species, particularly marine mammals. Payne and Webb were the first to hypothesize that sound emitted from modern ships significantly reduced the communication range of $20 \mathrm{~Hz}$ fin whale calls by up to 3000 nautical miles [14]. Using audiograms of the bottlenose dolphin (Tursiops truncatus), harbor seal (Phoca vitulina), and California sea lion (Zalophus californianus), Myrberg proposed that auditory masking of these species could occur from vessel traffic and industrial activities [15].

With the passage of the National Environmental Policy Act (NEPA) in 1969, the Marine Mammal Protection Act (MMPA) in 1972, and the Endangered Species Act in 1973 in the United States [16-19], government agencies faced the challenge of properly regulating various human activities that had been overlooked previously. The lack of science-based information to implement regulatory requirements and to assess environmental impacts from those activities prompted numerous studies investigating the effects of underwater sound on marine mammals $[4,5,20]$.

Some of the initial pressing questions were focused on the impacts that underwater detonations, typically used during naval shock trials and other exercises, may have on marine mammals [21]. Underwater detonation experiments were conducted using live animals such as sheep, dogs, and monkeys submerged in water to extrapolate the potential physical injuries and mortalities to marine mammals [21-23]. Those extrapolations, along with additional theoretical analysis on potential hearing impairment [24] and field observation of behavioral disturbance from sound exposure [25], were the basis for the U.S. Navy's (the Navy) environmental impact statement (EIS) for the shock trial of the Seawolf submarine [26].

In addition, from the early 1980s through the 1990s, the U.S. Minerals Management Service (MMS, the predecessor of the current Bureau of Ocean Energy Management (BOEM)) funded a number of studies to investigate adverse effects of oil and gas development activities on marine mammals in the Arctic. Most of those studies were based on aerial or vessel observations of marine mammal behavioral responses and movements when exposed to industrial activities, such as oil and gas exploration using seismic airgun arrays [27-39]. Many of those studies were reviewed by Myrberg [40] and summarized in a landmark book "Marine Mammals and Noise" by Richardson et al. [6].

A relatively simple scheme for assessing the impacts of sound on marine mammals was proposed by Richardson et al. [6] using the source-path-receiver model. In the model, potential adverse impacts from a given intense sound source are based on the distance of the source from the receiver (animal) (Figure 1). When the animal is in close proximity to the source, the impacts would be expected to be "severe" and physical injury could occur. When the animal is farther away from the source, the expected impacts would gradually decrease, until a distance at which the impacts would be negligible [6]. 


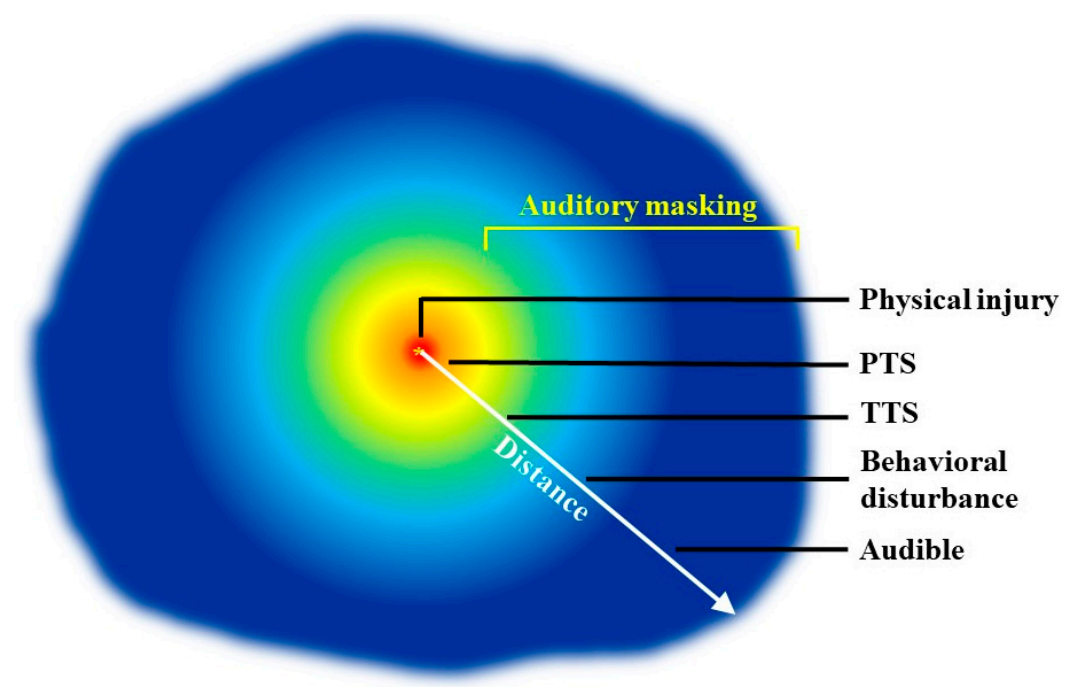

Figure 1. A simple acoustic impact model based on the distance of the source from the receiver (animal). PTS = permanent threshold shift; TTS = temporary threshold shift. See text for explanation.

Contrary to the simplicity of the model, the relationship between a given sound exposure level and the severity of the impact expected is not well defined. To delineate and assess impacts in a more meaningful manner, the 1994 amendments to the MMPA included definitions for both Level A and Level B harassment [41]. Based on the 1994 amendments, Level A harassment "has the potential to injure a marine mammal or marine mammal stock in the wild," while Level B harassment "has the potential to disturb a marine mammal or marine mammal stock in the wild by causing disruption of behavioral patterns, including, but not limited to, migration, breathing, nursing, breeding, feeding, or sheltering." A simple interpretation of Level A vs. Level B harassment is that Level A harassment could cause physical injury to a marine mammal, while Level B harassment could result in behavioral disturbance or displacement.

Given the lack of a standard for each type of impact, a number of different criteria, thresholds ${ }^{1}$, and metrics have been proposed and used in the impact assessment and review processes over the years (see [42]). For example, the Navy used the 50 percent tympanic membrane rupture criterion as onset of auditory injury for Level A harassment based on an energy flux density (EFD) of $1.17 \mathrm{in}-\mathrm{lb} / \mathrm{in}^{2}$ (equivalent to $205 \mathrm{~dB}$ re $1 \mu \mathrm{Pa}^{2}-\mathrm{s}$ ) in its EIS for the Seawolf shock trial $[20,26,42]$. In the same EIS, the Navy used dual criteria (based on two acoustic metrics) for Level B harassment: (1) an energy-based temporary threshold shift (TTS) threshold ${ }^{2}$ of $182 \mathrm{~dB}$ re $1 \mu \mathrm{Pa}^{2}$-s and (2) a peak pressure-based TTS threshold of $12 \mathrm{lb} / \mathrm{in}^{2}$ (or psi) [26,42]. At the time, the U.S. National Marine Fisheries Service (NMFS) used interim acoustic criteria for marine mammal harassment: $70 \mathrm{~dB}$ over a hearing threshold defined behavioral harassment, 80-100 dB over the threshold defined TTS, $133 \mathrm{~dB}$ over the threshold defined pain, and $155 \mathrm{~dB}$ over the threshold defined permanent threshold shift (PTS) [42,43].

Since information was unavailable concerning the onset of hearing injury in the form of PTS for marine mammals, an expert working group, the High Energy Seismic Survey Team (HESS Team) was convened by MMS in 1996 to provide a "roadmap" for applicants that used airgun arrays to acquire geophysical data and needed to comply with the various environmental statutes and regulations [43]. In its 1997 workshop, the HESS Team reached a consensus that exposures to root-mean-square sound pressure levels ( $S P L_{r m s}$ or $L_{\mathrm{p}, \mathrm{rms}}$ ) greater than $180 \mathrm{~dB}$ re $1 \mu \mathrm{Pa}_{\mathrm{rms}}$ were likely to have the potential to cause serious behavioral,

1 Only in-water thresholds are described in detail herein. Details regarding in-air thresholds are beyond the scope of the paper.

2 The metric considered the total energy of all exposures based on the greatest EFD in any one-third octave band for frequencies greater than $100 \mathrm{~Hz}$ for odontocetes and $10 \mathrm{~Hz}$ for mysticetes. 
physiological, and hearing effects [43]. Thus, $180 \mathrm{~dB}$ re $1 \mu \mathrm{Pa}_{\mathrm{rms}}$ became the Level A harassment threshold for cetaceans, and $190 \mathrm{~dB}$ re $1 \mu \mathrm{Pa}_{\text {rms }}$ was used for pinnipeds [44].

Malme et al. [29] documented that migrating gray whales (Eschrichtius robustus) avoided areas when exposed to continuous low-frequency sound levels above $120 \mathrm{~dB}$ re $1 \mu \mathrm{Pa}_{\mathrm{rms}}$ but female-calf pairs exhibited behavioral disturbances when exposed to impulsive sound levels above $160 \mathrm{~dB}$ re $1 \mu \mathrm{Pa}_{\text {rms }}$ [28,29]. Richardson et al. [32,35,45] documented similar responses in migrating bowhead whales. The 120 and $160 \mathrm{~dB}$ re $1 \mu \mathrm{Pa}_{\mathrm{rms}}$ sound levels were subsequently used as the onset Level B harassment thresholds for marine mammals when exposed to continuous and impulsive sound, respectively [44]. These Level B harassment thresholds continue to be used by the regulatory agencies for certain sound sources (e.g., seismic and high-resolution geophysical surveys, vibratory and impact pile driving, drilling).

Although hearing impairment, including TTS and PTS, had been widely documented in psychoacoustic studies on humans [46,47] and some terrestrial mammal species [48-50], the effects on marine mammals were only hypothesized until the mid-1990s (e.g., [4,6]). As a result, many of the impact assessments, with the exception of a few high-profile cases (e.g., Navy shock trials [26], military sonar [51], and the Acoustic Thermometry of Ocean Climate (ATOC) experiment [52]), did not consider the effects of TTS or PTS.

\section{Advances in Marine Mammal Psychoacoustic Research and the Consideration of Frequency-Based Auditory Responses in Impact Assessments: Since 2000}

The last 20 years have seen great progress in marine mammal psychoacoustic research, especially in the field of noise-induced threshold shift (NITS) studies. The first instance of NITS in a marine mammal was documented by Kastak and Schusterman [53], when a harbor seal was inadvertently exposed to intense broadband construction sound for 6 days, which resulted in a TTS of $8 \mathrm{~dB}$ at $100 \mathrm{~Hz}$. Soon afterwards, the U.S. Office of Naval Research funded a number of NITS studies to investigate marine mammal TTS by exposing the animals to various types of intense sounds (e.g., [54-59]). Many of the earlier studies were conducted on animals that were trained to respond to acoustic stimuli (behavioral or psychophysical methods), but more recently auditory evoked potentials (AEP) measurements (electrophysiological methods) have been used to study NITS (e.g., [60-64]). A comprehensive review of marine mammal NITS studies up to 2015 was provided by Finneran [65]. The results of those studies, coupled with behavioral and electrophysiological audiograms of approximately 20 marine mammal species, basic knowledge of their hearing capabilities (e.g., $[6,66,67])$, and known noise-induced PTS in humans, provided the foundation for assessing auditory injuries in marine mammals.

Around the same time in the early 2000s, naval exercises involving mid-frequency active sonar ${ }^{3}$ (MFAS) were purportedly linked to mass strandings of various deep-diving cetaceans, particularly beaked whales [68-72]. One of the hypotheses suggested that mortalities associated with sonar exposure-linked strandings were the result of decompression sickness (i.e., "the bends") due to rapid ascension to the sea surface by the mammals when exposed to MFAS sounds [73-75]. To fully understand whether behavioral responses from sonar exposure could be the cause of cetacean strandings, the Navy funded several controlled-exposure experiments (CEEs) beginning in the late-2000s (e.g., [76]). The researchers attached dataloggers equipped with various sensors (e.g., accelerometers, acoustic and pressure sensors) to individual whales and conducted playbacks of simulated MFAS or other anthropogenic sounds to the tagged animals. Behavioral responses of the exposed animals were analyzed from the recovered dataloggers [76-78]. More recently, actual naval sonar has been used to determine whether and how marine mammals respond to MFAS, e.g., [79]. Despite several large-scale CEEs that have been conducted around the world to address the effects of naval sonar on marine mammals, results have shown that 
responses are highly variable and may not be fully predictable with only sound level-based thresholds, e.g., [79-87].

Based on comprehensive review of the then up-to-date best available information, Southall et al. recommended a set of criteria for assessing sound exposure in marine mammals [88]. In their recommendations, marine mammals were grouped into five functional hearing groups based on their generalized auditory frequency responses and, for pinnipeds, the medium in which they listen. The functional hearing groups were: lowfrequency (LF) cetaceans (all baleen whales), mid-frequency (MF) cetaceans (delphinids, beaked whales, and the sperm whale), high-frequency (HF) cetaceans (porpoises, river dolphins, and Kogia spp.), pinnipeds in water, and pinnipeds in air. An "M-weighting" function representing a generic auditory frequency response was established for each of the five functional hearing groups using the paradigm similar to the human 100-phon equal-loudness function (or "C-weighting") [88].

Three sound types were identified in Southall et al.'s [88] criteria: (1) a single pulse, (2) multiple pulses, and (3) nonpulses. The distinction between pulse and nonpulse was determined based on a $3 \mathrm{~dB}$ difference between the continuous and impulse setting of a sound level meter (SLM). Specifically, if the SLM measurement from the impulse setting ( $35 \mathrm{~ms}$ ) was $3 \mathrm{~dB}$ or greater than the continuous setting $(1 \mathrm{~s})$ for the sound, that sound would be classified as a pulse, otherwise it would be deemed a nonpulse [88,89].

For assessing onset of auditory injury (defined as PTS), Southall et al. [88] recommended dual criteria for impact assessments, similar to the TTS criteria for the Seawolf shock trial EIS. The instantaneous pressure criteria were based on certain received peak sound pressure levels (SPL $L_{\text {peak }}$ or $L_{\mathrm{pk}}$ ) above which PTS could occur, while the total energy criteria were based on received cumulative sound exposure levels (SEL $L_{\mathrm{cum}}$ or $L_{\mathrm{E}}$ ) above

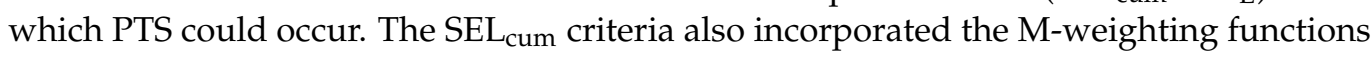
such that the sound source's frequency content, as well as its broadband sound levels, were

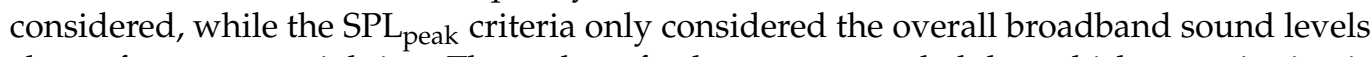
absent frequency weighting. The authors further recommended that whichever criterion is exceeded first (e.g., that which resulted in the largest impact zones) should be used as the operative injury criterion. The specific PTS thresholds were established by interpreting the available marine mammal TTS data and adding $6 \mathrm{~dB}$ to the TTS thresholds for the peak pressure metrics and $15 \mathrm{~dB}$ for the energy metrics [88]. For marine mammals where TTS data were lacking, such as LF cetaceans, their auditory anatomy (e.g., [66]) was considered along with extrapolations from MF cetacean TTS values [88].

For the onset of behavioral disturbance thresholds for single pulses, similar dual criteria were recommended based on marine mammal TTS-onset thresholds for cetaceans, pinnipeds in water, and pinnipeds in air [88]. For sound exposure from multiple pulses and nonpulses, Southall et al. [88] were not able to recommend a single value for each functional hearing group and acoustic metric. Instead, the authors conducted an extensive literature review and developed a "severity scale" system to rank the observed behavioral responses of marine mammals (both free-ranging and captive) exposed to a variety of anthropogenic sound with differing received $\mathrm{SPL}_{\mathrm{rms}}$ values [88]. At the time, the authors argued against using a single value for onset of behavioral disturbance from multiple pulses and nonpulses due to the vast variability and context-specific nature of animal responses to those types of sound.

The concepts from Southall et al.'s [88] recommendations soon became widely accepted and served as the basis for a renewed approach for conducting marine mammal impact assessments. In $2012^{4}$, the Navy released its first comprehensive compilation of the various criteria and thresholds for assessing impacts on marine mammals from acoustic and explosive sources [92]. Those criteria further updated the Southall et al. [88] recom-

4 At the same time, Wood et al. [90] developed simple probabilistic dose response functions for seismic surveys based on a given received level at 90 50, and 10 percent response rates for porpoises and beaked whales, migrating mysticetes, and all other species-the dose response functions also were intended to be used with the M-weighting functions. Variations of the Wood et al. [90] dose response functions have been used only once by the U.S. regulatory community [91]. 
mendations by modifying the M-weighting functions for cetaceans. Specifically, the Navy developed Type II weighting functions to account for both Type I weighting functions that were the same as, or similar to, M-weighting functions from Southall et al. [88] and an equal loudness weighting function that incorporated the increased susceptibility to sound observed by Finneran and Schlundt [93] in bottlenose dolphins. The Navy's 2012 criteria also divided pinnipeds into two functional hearing groups: phocids (eared seals or "true seals") and otariids (sea lions and fur seals) and added sirenians (manatees and dugong) to the phocid functional hearing group and odobenids (walruses), mustelids (sea otters and marine otters), and ursids (polar bear) to the otariid functional hearing group. In addition, the Navy's 2012 criteria consolidated various criteria into a set of six categories that were specific to underwater explosive sources: mortality, slight lung injury, gastrointestinal (GI) tract injury, PTS, TTS, and behavioral disturbance [92] $]^{5}$. Instead of using NMFS's generic 120 and $160 \mathrm{~dB}$ re $1 \mu \mathrm{Pa}_{\text {rms }}$ thresholds for onset of behavioral disturbance for acoustic sources, the Navy's 2012 criteria relied on behavioral response functions (BRFs) ${ }^{6}$ that were based on probabilistic Feller [94] functions it developed for its TAP I EISs ${ }^{7}$ for all functional hearing groups except beaked whales and harbor porpoises. The Navy used unweighted 140 and $120 \mathrm{~dB}$ re $1 \mu \mathrm{Pa}_{\mathrm{rms}}$ thresholds for assessing impacts on beaked whales and harbor porpoises, respectively, from acoustic sources. For explosive sources, the Navy used behavior thresholds that were $5 \mathrm{~dB}$ less than the TTS thresholds for each functional hearing group ${ }^{8}$. The Navy's 2012 criteria and thresholds were used in multiple Phase II EISs for the Navy's training and testing activities.

In 2016, the Navy drafted another technical report that provided updated marine mammal auditory weighting functions based on the human 40-phon equal-loudness function (or "A-weighting") and revised TTS and PTS thresholds [96]. Besides modifying various variables, methods, and functions for determining onset of TTS and PTS, the report also established sirenians as a separate functional hearing group [96]. The Navy also provided a singular equation to determine the weighting function amplitude, $W(f)$ in $\mathrm{dB}$, at a given frequency, $f$ in $\mathrm{kHz}$ :

$$
W(f)=C+10 \log _{10}\left\{\frac{\left(f / f_{1}\right)^{2 a}}{\left[1+\left(f / f_{1}\right)^{2}\right]^{a}\left[1+\left(f / f_{2}\right)^{2}\right]^{b}}\right\}
$$

where $C, f_{1}, f_{2}, a$ and $b$ are constants that define the shape of the filter for each functional hearing groups [96].

In the same year, the Navy's 2016 in-water criteria were incorporated into NMFS's technical guidance for assessing the effects of underwater sound on species under its jurisdiction (i.e., cetaceans and pinnipeds except odobenids) [97]. In 2018, NMFS released a revision to its 2016 technical guidance [98]. However, there were no substantial differences in the weighting functions or thresholds between the 2018 revision ${ }^{9}$ and the 2016 version. These criteria and thresholds currently are used by U.S. regulatory agencies for marine mammal impact assessments, primarily PTS for Level A harassment under the MMPA.

5 The Navy used many of the same criteria in its EISs for previous shock trials and for training and testing activities analyzed under the Tactical Training Theater Assessment and Planning (TAP I) documents.

6 Along with Type I weighting functions.

7 For more than two decades, the Navy also has used a metric it has termed "single ping equivalent" (SPE) to estimate behavioral responses of marine mammals to Surveillance Towed Array Sensor System Low Frequency Active (SURTASS LFA) sonar. SPE is a quasi-metric that the Navy has used to apply its SPE-based behavioral risk function, even though the metric is not based on any sort of physical quantity nor is it recognized by either the American National Standards Institute or the International Organization for Standardization. The U.S. Marine Mammal Commission, an independent oversight agency, has reviewed the deficiencies and inappropriatness of SPE and the underlying behavioral risk function [95].

8 The Navy, and thus NMFS, maintained and continues to maintain that the behavior thresholds only apply to multiple underwater detonations, not single detonations regardless of the net explosive weight.

9 Southall et al. [99] also recommended that the same weighting functions and TTS and PTS thresholds be used. However, the authors termed MF cetaceans as HF cetaceans and HF cetaceans as very high frequency (VHF) cetaceans. Southall et al. [99] developled a modified nomenclature that accounted for additional subdivisions within the LF and HF cetacean functional hearing groups but acknowledged that there were insufficient data to define further the exposure criteria within those subdivisions. 
TTS thresholds are considered Level B harassment under the MMPA and are used to assess impacts only from acoustic sources used in military readiness activities and from explosive sources used both in military readiness and construction activities. A summary of the current onset TTS and PTS thresholds for marine mammals, which originated from the Navy's 2016 technical report, is provided in Table 1.

Table 1. Summary of current marine mammal onset TTS and PTS thresholds (data from [96]). SEL $\mathrm{Sum}_{\text {cum }}$ thresholds in $\mathrm{dB}$ re $1 \mu \mathrm{Pa}^{2}$-s, $\mathrm{SPL}_{\text {peak }}$ thresholds in $\mathrm{dB}$ re $1 \mu \mathrm{Pa}_{\text {peak }}$.

\begin{tabular}{cccccccc}
\hline \multirow{2}{*}{ Functional Hearing Group } & \multicolumn{3}{c}{ Impulsive } & \multicolumn{3}{c}{ Non-Impulsive } \\
\cline { 2 - 7 } & \multicolumn{2}{c}{ TTS } & \multicolumn{2}{c}{ PTS } & TTS & PTS \\
\cline { 2 - 7 } & SEL $_{\text {cum }}$ & SPL $_{\text {peak }}$ & SEL $_{\text {cum }}$ & SPL $_{\text {peak }}$ & SEL $_{\text {cum }}$ & SEL $_{\text {cum }}$ \\
\hline LF & 168 & 213 & 183 & 219 & 179 & 199 \\
MF & 170 & 224 & 185 & 230 & 178 & 198 \\
HF & 140 & 196 & 155 & 202 & 153 & 173 \\
SI & 175 & 220 & 190 & 226 & 186 & 206 \\
OW & 188 & 226 & 203 & 232 & 199 & 219 \\
PW & 170 & 212 & 185 & 218 & 181 & 201
\end{tabular}

Notation: $\mathrm{LF}$ = low-frequency cetaceans; $\mathrm{MF}$ = mid-frequency cetaceans; $\mathrm{HF}=$ high-frequency cetaceans; $\mathrm{SI}=$ sirenians; $\mathrm{OW}=$ otariids in water (also includes odobenids, mustelids, and ursids); $\mathrm{PW}=$ phocids in water.

In 2017, the Navy released another round of updates to its marine mammal criteria and thresholds for the Phase III EISs for its training and testing activities [100]. The 2017 technical report retained all previous auditory weighting functions and the TTS and PTS thresholds but revised the Navy's behavior thresholds for acoustic sources ${ }^{10}$ and the mortality and slight lung and GI tract injury criteria and thresholds for explosive sources. Most notably, "cut-off distances" were introduced and defined as the distances beyond which significant behavioral responses to acoustic sources are unlikely to occur and harassment under the MMPA would not occur. The cut-off distances were used in conjunction with the unweighted $120 \mathrm{~dB}$ re $1 \mu \mathrm{Pa}_{\mathrm{rms}}$ threshold that the Navy continues to use for harbor porpoises and the Navy's revised BRFs for all other species. The Bayesian biphasic BRFs explicitly were intended to describe both level- and context-based responses as proposed by Ellison et al. [101]. At higher amplitudes, a level-based response relates the received sound level to the probability of a behavioral response, whereas, at lower amplitudes, sound can cue the presence, proximity, and approach of a sound source and stimulate a context-based response based on factors other than received sound level (e.g., the animal's previous experience, separation distance between sound source and animal, and behavioral state including feeding, traveling) [101].

\section{Application of Psychoacoustics in the Marine Mammal Regulatory Scheme: Successes and Deficiencies}

Decades of marine mammal psychoacoustic research has provided the much needed scientific basis for marine mammal management and policy. However, incorporation of scientific information into the regulatory scheme has proven to be a protracted process.

Among one of the biggest achievements in the application of best available science was the adoption of marine mammal auditory weighting functions for assessing auditory impacts, particularly for Level A harassment under the MMPA. This was a significant improvement from the previous generic Level A harassment thresholds of 180 and $190 \mathrm{~dB}$ re $1 \mu \mathrm{Pa}_{\mathrm{rms}}$. Since the weighting function equation can be easily solved analytically to derive the weighted $S E L_{\text {cum }}$ thresholds at a given frequency or frequencies, it is possible to estimate distances at which Level A harassment could occur using a spreadsheet and simplified assumptions [102]. However, such a simple approach for estimating injury

10 For explosive sources, the Navy again used behavior thresholds that were $5 \mathrm{~dB}$ less than the TTS thresholds for each functional hearing group and assumed that the behavior thresholds only apply to multiple underwater detonations. 
zones may not always be accurate. First, the simplified spreadsheet approach only uses geometrical spreading for sound propagation [7], and under certain circumstances (e.g., a moving source), only spherical spreading is incorporated [103]. Second, the estimation of $\mathrm{SEL}_{\text {cum }}$ for transient sounds does not consider potential recovery between exposuresbut neither does sophisticated modeling. Third, and the most serious shortcoming, the simplified spreadsheet approach assumes a stationary receiver that is exposed for the entire duration of the sound exposure, which can last as long as $24 \mathrm{~h}$. Often times, the distances at which Level A harassment can occur exceed the distances at which Level B harassment, specifically behavioral responses, occur [104-108]. To address this issue, as well as to calculate more realistic marine mammal take estimates, several models have been developed to incorporate simulations of marine mammal movements [109-114]. Those models include: Acoustic Integration Model (AIM) [109], Marine Mammal Movement and Behavior $(3 \mathrm{MB})^{11}$, Navy Acoustic Effects Model (NAEMO) [110,111], and JASCO Animal Simulation Model Including Noise Exposure (JASMINE) [115]. The parameters that seed the virtual marine mammals, or animats, are based on known animal distribution, behavior, and movement under various conditions [116-118]. Animat modeling can be embedded within simple spreadsheet tools to better inform the distances at which Level A harassment can occur and to avoid results that are contrary to common sense.

Regarding behavioral harassment and despite the large volume of studies conducted in the past few decades on marine mammal behavioral response to anthropogenic noise exposure, regulatory agencies continue to use the existing rudimentary thresholds of 120 and $160 \mathrm{~dB}$ re $1 \mu \mathrm{Pa}_{\mathrm{rms}}$ for onset of behavioral disturbance or Level B harassment under the MMPA for all activities except military readiness and underwater or confined detonations. The overly simplified threshold of $160 \mathrm{~dB}$ re $1 \mu \mathrm{Pa}_{\mathrm{rms}}$ that originally was intended to apply only to impulsive sounds has been systematically applied to all intermittent sounds, both impulsive and non-impulsive, by one regulatory agency, e.g., $[119,120]$ and to all sounds - continuous, intermittent, impulsive, and non-impulsive ${ }^{12}$ - by another agency, e.g., [121-123]. The rudimentary thresholds are not only outdated and not based on best available science, but they are being used in a manner that was never intended.

The Navy has made considerable progress in updating its behavior thresholds by way of its Bayesian BRFs for acoustic sources. The Bayesian BRFs were based on more applicable data and were a much needed update to the Navy's original Feller [94] function BRFs. However, use of cut-off distances by the Navy and subsequently NMFS has completely undermined the Bayesian BRFs' original intent. Specifically, inclusion of additional cut-off distances ${ }^{13}$ contradicts the data underlying the Bayesian BRFs, negates the intent of the functions themselves, and ultimately underestimates the numbers of takes, e.g., [124]. To investigate this issue further, Tyack and Thomas [125] compared results between setting a threshold where 50 percent of the animals respond and using the actual Bayesian BRF. Setting the threshold at a 50 percent response led to an underestimation of effect by a factor of 280 [125]. Given that the arbitrary cut-off distances were synonymous with an up to 45 percent response, the behavioral impacts and numbers of takes of the various species would have been underestimated as well [124]. As noted by Tyack and Thomas [125], given the shape of the dose-response function and how efficiently sound propagates in the ocean, the number of animals that are predicted to have a low probability of response may in fact represent the dominant impact from a given sound source.

For explosive sources, the behavior thresholds have yet to be updated and continue to be based on a value that was derived from observed onset behavioral responses of captive bottlenose dolphins during non-impulsive TTS testing of 1 sec tones [57]. In addition, the regulatory community only applies the behavior thresholds to multiple detonations and assumes that marine mammals would not be impacted by single detonations, including

3MB is available at http:/ / oalib.hlsresearch.com/Sound\%20and\%20Marine\%20Mammals/3MB\%20HTML.htm (accessed on 29 March 2021).

12 Including drilling, vibratory pile driving and removal, dynamic positioning systems and other vessel sounds.

13 Furthermore, the distances themselves are unsubstantiated. 
those with high net explosive weights. The justification for such an assumption is lacking. Moreover, the derivation of mortality and serious injury (GI tract and slight lung) thresholds continue to be based on terrestrial and domestic animals. While it is clear that directed research on these types of adverse impacts likely would not be permitted for marine mammals, the applicability of the previous studies to marine mammals is questionable. Such deficiencies highlight the importance of prompt retrieval, imaging, and necropsy of animals unintentionally killed by underwater detonations, i.e., common dolphins killed at Silver Strand [126].

Despite the availability of tools to assess the impacts of sound on marine mammals, the regulatory community has yet to incorporate the latest scientific information or use the tools (e.g., animats) and models (e.g., sound propagation models) in-house for its impact assessments [7]. This has prevented regulatory agencies from determining more realistic estimates when calculating harassment takes. Rather, the agencies generally use the simplest arithmetic method of calculating marine mammal takes $(N)$ using the equation [127]:

$$
N=D \times A \times T
$$

where $D$ is the animal density (number $\left./ \mathrm{km}^{2}\right)$ in the area, $A$ is the ensonified area $\left(\mathrm{km}^{2}\right)$, and $T$ is the project duration (days).

The failure to incorporate information on marine mammal behavior, distribution, and densities to ground-truth arithmetic results has often yielded unrealistic take estimates. For example, when assessing the potential behavioral disturbance of harbor seals from a small mooring float construction project at Sentinel Island in Alaska that involved installing up to six 24 in piles on up to six days, one regulatory agency estimated that a total of 36,180 harbor seal takes could occur, among a presumed local population of approximately 134 animals [128]. Since the same regulatory agency assumes that a marine mammal can be taken only once on a given day, the maximum number of takes for the project would have been less than 1000 seals. Although determining whether and how to use pinniped haul-out counts appropriately, when such counts should be adjusted based on haul-out correction factors or time spent at sea (e.g., [124,129-132]), and whether certain animal movement models (e.g., [133]) are appropriate may be challenging, such evaluations are necessary for ensuring that take estimates are informed by the basic biology of the species.

\section{Future Needs in Marine Mammal Psychoacoustic Research}

Despite the achievements made in the first 20 years of the 21st century toward understanding marine mammal NITS, auditory effects on many taxa (or functional hearing groups) have still not been studied empirically. Specifically, there are no audiograms or TTS data from mysticetes (LF cetaceans). Hearing sensitivities of those species only have been derived theoretically based on anatomical observation and modeling [134-139].

Similarly, for many large odontocetes, such as the sperm whale (Physeter macrocephalus) and beaked whales (Ziphiidae), there are very few measured audiograms [140-142]. Therefore, hearing sensitivity and TTS thresholds for those species are largely extrapolated from a few species of delphinids (MF cetaceans). The same is true for HF cetaceans, which include a number of species from different taxa but the composite audiogram was derived from the harbor porpoise (Phocoena phocoena), finless porpoise (Neophocoena pocaenoides), and three species of river dolphins [88]. Data similarly are scant for otariids, walruses, sea otters, and sirenians and non-existent for polar bears [88]. Further research on audiograms and TTS for data-poor marine mammal species will provide further insights needed to validate or revise the existing weighting functions used by the regulatory community [99].

While it has been recognized that impulsive sounds generally are more harmful than non-impulsive sounds in terms of auditory effects [143-148], there are certain situations where both impulsive and non-impulsive sound occur simultaneously. For example, downthe-hole (DTH) pile installation is one such source that generates complex sounds [149]. The authors are unaware of any NITS study that has been conducted on marine mammals exposed to complex sounds, despite the fact that studies on human and terrestrial species 
have shown that exposure to such sounds is more detrimental than to pure non-impulsive continuous sounds [150-154].

Additionally, neither sufficient nor appropriate data currently exist to develop sophisticated BRFs for sources other than MFAS $[100,155,156]$. For example, data are lacking regarding near-field behavioral response effects from seismic surveys and in general for behavioral responses of species other than mysticetes and sperm whales, e.g., [157-160]. Similarly, near-field behavioral response data are lacking for pile-driving and -removal activities for all species, while far-field data generally exist only for harbor porpoises and harbor seals, primarily from studies at large-scale wind farms in Europe where larger diameter piles are installed ${ }^{14}$ than for coastal construction projects, e.g., [162,163]. A plethora of monitoring data are available for coastal construction projects in the United States ${ }^{15}$. However, much of the data have not been collected in a manner or with sufficient specificity to determine what, if any, behavioral response may have occurred at a given received level. Moreover, behavioral response data are lacking for LFAS sources, such as SURTASS LFA sonar, and underwater and confined detonations. Further research is needed to inform source-specific ${ }^{16} \mathrm{BRF}$ for the various groups of marine mammals.

The interpretation of behavioral response data in relation to biologically significant impacts remains a challenge. Many factors, such as age and sex, behavioral context, motivation, and naivety of the animal need to be considered when interpreting behavioral response, or the lack thereof [101]. Many of these factors cannot be easily quantified (see [88]). Regardless, the current step function thresholds for the onset of behavioral disturbance for two generalized sound types are overly simplistic. At a minimum and until such time that more sophisticated BRFs are developed, dose response functions similar to those from Wood et al. [90] should be adopted to better assess behavioral disturbance of marine mammals. Researchers developing BRFs also should provide quantile response data at given received levels (see Table IV in Miller et al. [156]) to allow regulators that are unable to implement dose response functions to implement the quantiles using simple spreadsheets [125].

Quantifying how sub-lethal impacts, particularly behavioral disturbance, translate to population-level impacts has been challenging for the regulatory community. In more recent years, frameworks have been developed and various case studies have been investigated to link quantitatively behavioral responses of individuals to impacts to the population as a whole, see [164-170]. For many marine mammal populations, baseline data necessary to inform such analyses are lacking [171]. As such, basic demographic, physiological, and health data should be collected to inform future population-level impact assessments.

Compared to behavioral disturbance, auditory masking is a relatively less studied area in marine mammal psychoacoustic research $[172,173]$. Auditory masking of biologically important acoustic signals can lead to a reduced communication space $[14,174,175]$ and, for species that largely rely on acoustic cues for their life functions, should be considered a significant issue in marine mammal conservation $[176,177]$. This is particularly true in regard to vessel traffic, which is not currently regulated by U.S. regulatory agencies.

Marine mammals exposed to elevated background sound have been observed to change their vocal behaviors to compensate, including increasing the length or repetition rates of the calls [160,178-181], shifting call frequencies [182], or increasing call intensities [181,183-189] (which also is known as Lombard effect [190]). It is likely that some of these vocal behavioral changes could be energetically costly [191-193].

14 Acoustic deterrent devices also are used to deter marine mammals from close ranges, which add a confounding factor to any behavioral response data collected [161].

15 https://www.fisheries.noaa.gov/national/marine-mammal-protection/incidental-take-authorizations-construction-activities (accessed on 29 March 2021).

16 Or groups of similar sources. For example, BRFs could be developed for vibratory pile driving and drilling combined or BRFs for seismic surveys could apply to underwater and confined detonations if data are lacking. 
While there are many studies on the cause-effect relationship between chronic sound exposure and physiological stress and overall health in humans [194-199], fewer studies have been conducted on marine mammals. Based on evidence from terrestrial mammals and humans, it has long been suspected chronic sound exposure is a potential source of stress for marine mammals [200]. Although numerous techniques are widely used to assess marine mammal health status by examining stress-related hormone biomarkers or gene expression index [201-205], the cause and effect that links sound exposure to physiological impacts or health status are often difficult to ascertain due to the compounding nature of the stressors.

It also is worth noting that anthropogenic sound is just one of the many stressors that may affect marine mammals. As the marine environment is undergoing unprecedented changes, cumulative effects arising from a wide range of stressors, such as climate change, overfishing, pollution, habitat loss, and ocean acidification, must be considered [206-209]. The specific topic of cumulative impacts is beyond the scope of this paper. Nevertheless, additional research is needed to incorporate and evaluate multiple stressors and assess the cumulative impact of those stressors on marine mammals, similar to what has been described by the National Academies of Sciences [207].

Last but not the least, all the scientific and technological advances in marine mammal psychoacoustics will not improve management and implementation of appropriate conservation measures if regulatory agencies do not have the expertise and skills to translate science into policy. It is encouraging that several government agencies, such as the Navy $[210,211]$ and BOEM ${ }^{17}$, have taken tremendous steps in building their internal capacity by funding underwater acoustic studies and conducting modeling for environmental impact assessments, while other agencies have yet to do so. All agencies with regulatory responsibilities for evaluating the potential impacts of sound on marine mammals must make it a priority to bolster their internal capacity, in terms of both determining whether the analyses provided are scientifically sound and incorporating the most recent and best available science into their marine mammal take assessments. A lack of science-based management can have legal and, more importantly, conservation implications for marine mammals, including for those populations that are declining.

Author Contributions: Conceptualization, S.G. and T.B.; writing-original draft, S.G. and T.B.; review and revisions, S.G. and T.B. All authors have read and agreed to the published version of the manuscript.

Funding: This research received no external funding.

Acknowledgments: The authors thank Peter Thomas for a thorough review of and comments on this manuscript. The authors also appreciate the constructive comments from two anonymous reviewers.

Conflicts of Interest: The authors declare no conflict of interest.

\section{References}

1. Duarte, C.M.; Chapuis, L.; Collin, S.P.; Costa, D.P.; Devassy, R.P.; Eguiluz, V.M.; Erbe, C.; Gordon, T.A.C.; Halpern, B.S.; Harding, H.R.; et al. The soundscape of the anthropocene ocean. Science 2021, 371. [CrossRef] [PubMed]

2. National Research Council. Marine Mammal. Populations and Ocean. Noise: Determining When Noise Causes Biologically Significant Effects; National Academies Press: Washington, DC, USA, 2005.

3. Nowacek, D.P.; Thorne, L.H.; Johnston, D.W.; Tyack, P.L. Responses of cetaceans to anthropogenic noise. Mamm. Rev. 2007, 37, 81-115. [CrossRef]

4. National Research Council. Low-Frequency Sound and Marine Mammals: Current Knowledge and Research Needs; The National Academies Press: Washington, DC, USA, 1994.

5. Shannon, G.; McKenna, M.F.; Angeloni, L.M.; Crooks, K.R.; Fristrup, K.M.; Brown, E.; Warner, K.A.; Nelson, M.D.; White, C.; Briggs, J.; et al. A synthesis of two decades of research documenting the effects of noise on wildlife. Biol. Rev. 2016, 91, 982-1005. [CrossRef]

17 BOEM recently established the Center for Marine Acoustics that is staffed with experts to conduct underwater acoustic and animat modeling in support of its environmental impact assessments. https:/ / www.boem.gov/center-marine-acoustics (accessed on 21 March 2021). 
6. Richardson, W.J.; Malme, C.I.; Thomson, D.H.; Greene, C.R. Marine Mammals and Noise; Academic Press: San Diego, CA, USA, 1995.

7. Guan, S.; Brookens, T.; Vignola, J. Use of underwater acoustics in marine conservation and policy: Previous advances, current status, and future needs. J. Mar. Sci. Eng. 2021, 9, 173. [CrossRef]

8. Lasky, M. Review of undersea acoustics to 1950. J. Acoust. Soc. Am. 1977, 61, 283-297. [CrossRef]

9. Bjørnø, L. Features of underwater acoustics from Aristotle to our time. Acoust. Phys. 2003, 49, 24-30. [CrossRef]

10. Schevill, W.E.; Lawrence, B. Underwater listening to the white porpoise (Delphinapterus leucas). Science 1949, 109, 143-144. [CrossRef] [PubMed]

11. Kellogg, W.N.; Kohler, R.; Morris, H.N. Porpoise sounds as sonar signals. Science 1953, 117, 239-243. [CrossRef] [PubMed]

12. Ray, C.; Watkins, W.A.; Burns, J.J. The underwater song of Erignathus (bearded seal). Zool. N. Y. Zool. Soc. 1969, $54,79-83$.

13. Payne, R.S.; McVay, S. Songs of humpback whales. Science 1971, 173, 585-597. [CrossRef]

14. Payne, R.; Webb, D. Orientation by means of long range acoustic signaling in baleen whales. Ann. N. Y. Acad. Sci. 1971, 188, 110-141. [CrossRef] [PubMed]

15. Myrberg, A.A., Jr. Ocean noise and the behavior of marine animals: Relationships and implications. In Effects of Noise on Wildlife; Academic Press: New York, NY, USA, 1978; pp. 169-208.

16. Llewellyn, L.G.; Peiser, C. NEPA and the Environmental Movement: A Brief. History; National Bureau of Standards: Washington, DC, USA, 1973.

17. Doub, J.P. The Endangered Species Act.: History, Implementation, Successes, and Controversies, 1st ed.; CRC Press: Boca Raton, FL, USA, 2016.

18. Roman, J.; Altman, I.; Dunphy-Daly, M.M.; Campbell, C.; Jasny, M.; Read, A.J. The Marine Mammal Protection Act at 40: Status, recovery, and future of U.S. marine mammals. Ann. N. Y. Acad. Sci. 2013, 1286, 29-49. [CrossRef] [PubMed]

19. Greenwald, N.; Suckling, K.F.; Hartl, B.; Mehrhoff, L.A. Extinction and the U.S. Endangered Species Act. PeerJ 2019, 7. [CrossRef] [PubMed]

20. Gisiner, R.C. Workshop on the Effects of Anthropogenic Noise in the Marine Environment; Office of Naval Research: Arlington, VA, USA, 1998.

21. Goertner, J.F. Prediction of Underwater Explosion Safe. Range for Sea Mammals; Naval Surface Weapons Center (CODE R15); White Oak: Silver Spring, MD, USA, 1982.

22. Richmond, D.; Yelverton, J.; Fletcher, E. Far-Field Underwater-Blast Injuries Produced by Small Charges; Defense Nuclear Agency: Washington, DC, USA, 1973.

23. Yelverton, J.T.; Richmond, D.R.; Fletcher, E.R.; Jones, R.K. Safe. Distances from Underwater Explosions for Mammals and Birds; Lovelace Foundation for Medical Education and Research: Albuquerque, NM, USA, 1973.

24. Ketten, D.R. Estimates of blast injury and acoustic trauma zones for marine mammals from underwater explosions. In Sensory Systems of Aquatic Mammals; Kastelein, R.A., Thomas, J.A., Nachtigall, P.E., Eds.; De Spil Publishers: Woerden, The Netherlands, 1995; pp. 391-407; ISBN 90-72743-05-9.

25. Todd, S.; Lien, J.; Marques, F.; Stevick, P.; Ketten, D. Behavioural effects of exposure to underwater explosions in humpback whales (Megaptera novaeangliae). Can. J. Zool. 1996, 74, 1661-1672. [CrossRef]

26. U.S. Navy. Final Environmental Impact Statement: Shock Testing the Seawolf Submarine; Naval Facilities Engineering Command, Southern Division: North Charleston, SC, USA, 1998.

27. Richardson, W.J. Behavior, Disturbance Responses and Distribution of Bowhead Whales Balaena mysticetus in the Eastern Beaufort Sea, 1982; U.S. Department of the Interior, Minerals Management Service: Reston, VA, USA, 1983.

28. Malme, C.I.; Miles, P.R.; Clark, C.W.; Tyack, P.; Bird, J.E. Investigations of the Potential Effects of Underwater Noise from Petroleum Industry Activities on Migrating Gray Whale Behavior; U.S. Department of the Interior, Minerals Management Service: Anchorage, AK, USA, 1983.

29. Malme, C.I.; Miles, P.R.; Clark, C.W.; Tyack, P.; Bird, J.E. Investigations of the Potential Effects of Underwater Noise from Petroleum Industry Activities on Migrating Gray Whale Behavior-Phase II: January 1984 Migration; U.S. Department of the Interior, Minerals Management Service: Anchorage, AK, USA, 1984.

30. Ljungblad, D.K.; Würsig, B.; Reeves, R.R.; Clarke, J.; Greene, C.R., Jr. Fall 1983 Beaufort Sea Seismic Monitoring and Bowhead Whale Behavior Studies; Minerals Management Service: Anchorage, AK, USA, 1984.

31. Malme, C.I.; Miles, P.; Tyack, P.; Clark, C.; Bird, J.E. Investigations of the Potential Effects of Underwater Noise from Petroleum Industry Activities on Feeding Humpback Whale Behavior; U.S. Department of the Interior, Minerals Management Service: Anchorage, AK, USA, 1985.

32. Richardson, W.J.; Fraker, M.A.; Würsig, B.; Wells, R.S. Behaviour of bowhead whales Balaena mysticetus summering in the Beaufort Sea: Reactions to industrial activities. Biol. Conserv. 1985, 32, 195-230. [CrossRef]

33. Fraker, M.A.; Ljungblad, D.K.; Richardson, W.J.; Van Schoik, D.R. Bowhead Whale Behavior in Relation to Seismic Exploration, Alaska Beaufort Sea, Autumn 1981; U.S. Department of the Interior, Minerals Management Service: Reston, VA, USA, 1985.

34. Richardson, W.J. Behavior, Disturbance Responses and Distribution of Bowhead Whales Balaena mysticetus in the Eastern Beaufort Sea. 1980-1984; LGL Ecological Research Associates, Inc.: Bryan, TX, USA, 1985.

35. Richardson, W.J.; Würsig, B.; Greene, C.R. Reactions of bowhead whales, Balaena mysticetus, to seismic exploration in the Canadian Beaufort Sea. J. Acoust. Soc. Am. 1986, 79, 1117-1128. [CrossRef] [PubMed] 
36. Richardson, W.J.; Davis, R.A.; Evans, C.R.; Ljungblad, D.K.; Norton, P. Summer distribution of bowhead whales, Balaena mysticetus, relative to oil industry activities in the Canadian Beaufort Sea, 1980-1984. Arctic 1987, 40, 93-104. [CrossRef]

37. Ljungblad, D.K.; Würsig, B.; Swartz, S.L.; Keene, J.M. Observations on the behavioral responses of bowhead whales (Balaena mysticetus) to active geophysical vessels in the Alaskan Beaufort Sea. Arctic 1988, 41, 183-194. [CrossRef]

38. Johnson, S.R.; Burns, J.J.; Malme, C.I.; Davis, R.A. Synthesis of Information on the Effects of Noise and Disturbance on Major Haulout Concentrations of Bering Sea Pinnipeds; U.S. Department of the Interior, Minerals Management Service: Anchorage, AK, USA, 1989.

39. Richardson, W.J.; Greene, C.R., Jr.; Hanna, J.S.; Koski, W.R.; Miller, G.W.; Patenaude, N.J.; Smultea, M.A. Acoustic Effects of Oil Production Activities on Bowhead and White Whales Visible during Spring Migration Near Pt. Barrow, Alaska-1991 and 1994 Phases: Sound Propagation and Whale Responses to Playbacks of Icebreaker Noise; Mineral Management Service: Herndon, VA, USA, 1995.

40. Myrberg, A.A. The effects of man-made noise on the behavior of marine animals. Environ. Int. 1990, 16, 575-586. [CrossRef]

41. National Research Council. Marine Mammals and Low-Frequency Sound: Progress Since 1994; National Academies Press: Washington, DC, USA, 2000.

42. Cavanagh, R.C. Criteria and Thresholds for Adverse Effects of Underwater Noise on Marine Animals; Air Force Research Laboratory: Dayton, OH, USA, 2000.

43. High Energy Seismic Survey. High Energy Seismic Survey Review Process and Interim Operational Guidelines for Marine Surveys Offshore Southern California; The High Energy Seismic Survey Team: Santa Barbara, CA, USA, 1999.

44. Scholik-Schlomer, A.R. Where the decibels hit the water: Perspectives on the application of science to real-world underwater noise and marine protected species issues. Acoust. Today 2015, 11, 36-44.

45. Richardson, W.J.; Würsig, B.; Greene, C.R. Reactions of bowhead whales, Balaena mysticetus, to drilling and dredging noise in the Canadian Beaufort Sea. Mar. Environ. Res. 1990, 29, 135-160. [CrossRef]

46. Kryter, K.D. Effects of Noise on Man; Academic Press: New York, NY, USA, 1970.

47. Nixon, C.W.; Krantz, D.W.; Johnson, D.L. Human Temporary Threshold Shift and Recovery from 24 Hour Acoustic Exposures; Defense Technical Information Center: Fort Belvoir, VA, USA, 1975.

48. Davis, H. Acoustic Trauma in the Guinea Pig. J. Acoust. Soc. Am. 1953, 25, 1180-1189. [CrossRef]

49. Peters, E.N. Temporary Shifts in auditory thresholds of chinchilla after exposure to noise. J. Acoust. Soc. Am. 1965, 37, 831-833. [CrossRef] [PubMed]

50. Benitez, L.D.; Eldredge, D.H.; Templer, J.W. Temporary threshold shifts in chinchilla: Electrophysiological correlates. J. Acoust. Soc. Am. 1972, 52, 1115-1123. [CrossRef]

51. U.S. Navy. Draft Overseas Environmental Impact Statement and Environmental Impact Statement for Surveillance Towed Array Sensor System Low Frequency Active (SURTASS LFA) Sonar; Department of the Navy, Chief of Naval Operations: Arlington, VA, USA, 1999.

52. Advanced Research Projects Agency. Final Environmental Impact Statement for the Kauai Acoustic Thermometry of Ocean. Climate Project and Its Associated Marine Mammal. Research Program. (Scientific Research Permit Application [P557E]); Advanced Research Projects Agency: Arlington, VA, USA, 1995; Volume 1.

53. Kastak, D.; Schusterman, R.J. Temporary threshold shift in a harbor seal (Phoca vitulina). J. Acoust. Soc. Am. 1996, 100, 1905-1908. [CrossRef] [PubMed]

54. Ridgway, S.H.; Carter, D.A.; Smith, R.R.; Kamolnick, T.; Schlundt, C.E. Behavioral Responses and Temporary Shift in Masked Hearing Threshold of Bottlenose Dolphins, Tursiops truncatus, to 1-Second Tones of 141 to $201 \mathrm{~dB}$ re $1 \mu \mathrm{Pa}$; Naval Command, Control, and Ocean Surveillance Center, RDT\&E Division: San Diego, CA, USA, 1997.

55. Kastak, D.; Schusterman, R.J.; Southall, B.L.; Reichmuth, C.J. Underwater temporary threshold shift induced by octave-band noise in three species of pinniped. J. Acoust. Soc. Am. 1999, 106, 1142-1148. [CrossRef]

56. Finneran, J.J.; Schlundt, C.E.; Carder, D.A.; Clark, J.A.; Young, J.A.; Gaspin, J.B.; Ridgway, S.H. Auditory and behavioral responses of bottlenose dolphins (Tursiops truncatus) and a beluga whale (Delphinapterus leucas) to impulsive sounds resembling distant signatures of underwater explosions. J. Acoust. Soc. Am. 2000, 108, 417-431. [CrossRef]

57. Schlundt, C.E.; Finneran, J.J.; Carder, D.A.; Ridgway, S.H. Temporary shift in masked hearing thresholds of bottlenose dolphins, Tursiops truncatus, and white whales, Delphinapterus leucas, after exposure to intense tones. J. Acoust. Soc. Am. 2000, 107, 3496-3508. [CrossRef]

58. Finneran, J.J.; Schlundt, C.E.; Dear, R.; Carder, D.A.; Ridgway, S.H. Temporary shift in masked hearing thresholds in odontocetes after exposure to single underwater impulses from a seismic watergun. J. Acoust. Soc. Am. 2002, 111, 2929-2940. [CrossRef]

59. Nachtigall, P.E.; Pawloski, J.L.; Au, W.W.L. Temporary threshold shifts and recovery following noise exposure in the Atlantic bottlenosed dolphin (Tursiops truncatus). J. Acoust. Soc. Am. 2003, 113, 3425-3429. [CrossRef]

60. Nachtigall, P.E.; Supin, A.Y.; Pawloski, J.; Au, W.W.L. Temporary threshold shifts after noise exposure in the bottlenose dolphin (Tursiops truncatus) measured using evoked auditory potentials. Mar. Mamm. Sci. 2004, 20, 673-687. [CrossRef]

61. Finneran, J.J.; Schlundt, C.E.; Branstetter, B.; Dear, R.L. Assessing temporary threshold shift in a bottlenose dolphin (Tursiops truncatus) using multiple simultaneous auditory evoked potentials. J. Acoust. Soc. Am. 2007, 122, 1249-1264. [CrossRef]

62. Lucke, K.; Siebert, U.; Lepper, P.A.; Blanchet, M.-A. Temporary shift in masked hearing thresholds in a harbor porpoise (Phocoena phocoena) after exposure to seismic airgun stimuli. J. Acoust. Soc. Am. 2009, 125, 4060-4070. [CrossRef] [PubMed]

63. Popov, V.V.; Klishin, V.O.; Nechaev, D.I.; Pletenko, M.G.; Rozhnov, V.V.; Supin, A.Y.; Sysueva, E.V.; Tarakanov, M.B. Influence of acoustic noises on the white whale hearing thresholds. Dokl. Biol. Sci. 2011, 440, 332-334. [CrossRef] [PubMed] 
64. Popov, V.V.; Supin, A.Y.; Wang, D.; Wang, K.; Dong, L.; Wang, S. Noise-induced temporary threshold shift and recovery in Yangtze finless porpoises Neophocaena phocaenoides asiaeorientalis. J. Acoust. Soc. Am. 2011, 130, 574-584. [CrossRef]

65. Finneran, J.J. Noise-induced hearing loss in marine mammals: A review of temporary threshold shift studies from 1996 to $2015 . J$. Acoust. Soc. Am. 2015, 138, 1702-1726. [CrossRef]

66. Wartzok, D.; Ketten, D. Marine Mammal Sensory Systems. In Biology of Marine Mammals; Smithsonian Institute Press: Washington, DC, USA, 1999; pp. 117-175.

67. Houser, D.S.; Helweg, D.A.; Moore, P.W.B. A bandpass filter-bank model of auditory sensitivity in the humpback whale. Aquat. Mamm. 2001, 27, 82-92.

68. Balcomb, K.C., III; Claridge, D.E. A mass stranding of cetaceans caused by naval sonar in the Bahamas. Bahamas J. Sci. 2001, 8, $1-12$.

69. Evans, D.L.; England, G.R. Joint Interim Report Bahamas Marine Mammal. Stranding Event of 15-16 March 2000; National Oceanic and Atmospheric Administration: Silver Spring, MD, USA, 2001.

70. Schrope, M. Whale deaths caused by US Navy's sonar. Nature 2002, 415, 106. [CrossRef] [PubMed]

71. D'Amico, A.; Gisiner, R.C.; Ketten, D.R.; Hammock, J.A.; Johnson, C.; Tyack, P.L.; Mead, J. Beaked whale strandings and naval exercises. Aquat. Mamm. 2009, 35, 452-472. [CrossRef]

72. Filadelfo, R.; Pinelis, Y.K.; Davis, S.; Chase, R.; Mintz, J.; Wolfanger, J.; Tyack, P.L.; Ketten, D.; D'Amico, A. Correlating military sonar use with beaked whale mass strandings: What do the historical data show? Aquat. Mamm. 2009, 35, 445-451. [CrossRef]

73. Jepson, P.D.; Arbelo, M.; Deaville, R.; Patterson, I.A.P.; Castro, P.; Baker, J.R.; Degollada, E.; Ross, H.M.; Herráez, P.; Pocknell, A.M.; et al. Gas-bubble lesions in stranded cetaceans. Nature 2003, 425, 575-576. [CrossRef] [PubMed]

74. Jepson, P.D.; Deaville, R.; Patterson, I.A.P.; Pocknell, A.M.; Ross, H.M.; Baker, J.R.; Howie, F.E.; Reid, R.J.; Colloff, A.; Cunningham, A.A. Acute and chronic gas bubble lesions in cetaceans stranded in the United Kingdom. Vet. Pathol. 2005, 42, 291-305. [CrossRef] [PubMed]

75. Fernández, A.; Edwards, J.F.; Rodríguez, F.; de los Monteros, A.E.; Herráez, P.; Castro, P.; Jaber, J.R.; Martín, V.; Arbelo, M. “Gas and fat embolic syndrome" involving a mass stranding of beaked whales (family Ziphiidae) exposed to anthropogenic sonar signals. Vet. Pathol. 2005, 42, 446-457. [CrossRef]

76. Southall, B. Biological and Behavioral Response Studies of Marine Mammals in Southern California, 2011 ("SOCAL-11") Final Project Report; Naval Postgraduate School: Monterey, CA, USA, 2012.

77. Tyack, P.; Gordon, J.; Thompson, D. Controlled-exposure experiments to determine the effects of noise on marine mammals. Mar. Technol. Soc. J. 2003, 37, 39-51. [CrossRef]

78. Tyack, P.L.; Zimmer, W.M.X.; Moretti, D.; Southall, B.L.; Claridge, D.E.; Durban, J.W.; Clark, C.W.; D'Amico, A.; DiMarzio, N.; Jarvis, S.; et al. Beaked whales respond to simulated and actual Navy sonar. PLoS ONE 2011, 6, e17009. [CrossRef]

79. Falcone, E.A.; Schorr, G.S.; Watwood, S.L.; DeRuiter, S.L.; Zerbini, A.N.; Andrews, R.D.; Morrissey, R.P.; Moretti, D.J. Diving behaviour of Cuvier's beaked whales exposed to two types of military sonar. R. Soc. Open Sci. 2017, 4, 170629. [CrossRef]

80. Sivle, L.D.; Kvadsheim, P.H.; Fahlman, A.; Lam, F.P.A.; Tyack, P.L.; Miller, P.J.O. Changes in dive behavior during naval sonar exposure in killer whales, long-finned pilot whales, and sperm whales. Front. Physiol. 2012, 3. [CrossRef]

81. DeRuiter, S.L.; Southall, B.L.; Calambokidis, J.; Zimmer, W.M.X.; Sadykova, D.; Falcone, E.A.; Friedlaender, A.S.; Joseph, J.E.; Moretti, D.; Schorr, G.S.; et al. First direct measurements of behavioural responses by Cuvier's beaked whales to mid-frequency active sonar. Biol. Lett. 2013, 9, 20130223. [CrossRef]

82. Goldbogen, J.A.; Southall, B.L.; DeRuiter, S.L.; Calambokidis, J.; Friedlaender, A.S.; Hazen, E.L.; Falcone, E.A.; Schorr, G.S.; Douglas, A.; Moretti, D.J.; et al. Blue whales respond to simulated mid-frequency military sonar. Proc. R. Soc. B Biol. Sci. 2013, 280, 20130657. [CrossRef]

83. Stimpert, A.K.; DeRuiter, S.L.; Southall, B.L.; Moretti, D.J.; Falcone, E.A.; Goldbogen, J.A.; Friedlaender, A.; Schorr, G.S.; Calambokidis, J. Acoustic and foraging behavior of a Baird's beaked whale, Berardius bairdii, exposed to simulated sonar. Sci. Rep. 2014, 4, 7031. [CrossRef] [PubMed]

84. Sivle, L.D.; Kvadsheim, P.H.; Curé, C.; Isojunno, S.; Wensveen, P.J.; Lam, F.-P.A.; Visser, F.; Kleivane, L.; Tyack, P.L.; Harris, C.M.; et al. Severity of expert-identified behavioural responses of humpback whale, minke whale, and northern bottlenose whale to naval sonar. Aquat. Mamm. 2015, 41, 469-502. [CrossRef]

85. Southall, B.; Nowacek, D.; Miller, P.; Tyack, P. Experimental field studies to measure behavioral responses of cetaceans to sonar. Endang. Species. Res. 2016, 31, 293-315. [CrossRef]

86. Curé, C.; Isojunno, S.; Visser, F.; Wensveen, P.; Sivle, L.; Kvadsheim, P.; Lam, F.; Miller, P. Biological significance of sperm whale responses to sonar: Comparison with anti-predator responses. Endang. Species. Res. 2016, 31, 89-102. [CrossRef]

87. Southall, B.L.; DeRuiter, S.L.; Friedlaender, A.; Stimpert, A.K.; Goldbogen, J.A.; Hazen, E.; Casey, C.; Fregosi, S.; Cade, D.E.; Allen, A.N.; et al. Behavioral responses of individual blue whales (Balaenoptera musculus) to mid-frequency military sonar. J. Exp. Biol. 2019, 222. [CrossRef] [PubMed]

88. Southall, B.L.; Bowles, A.E.; Ellison, W.T.; Finneran, J.J.; Gentry, R.L.; Greene, C.R., Jr.; Kastak, D.K.; Ketten, D.R.; Miller, J.H.; Nachtigall, P.E.; et al. Marine mammal noise exposure criteria: Initial scientific recommendations. Aquat. Mamm. 2007, 33, 411-521. [CrossRef]

89. Harris, C.M. Handbook of Acoustical Measurements and Noise Control, 3rd ed.; American Institute of Physics: Woodbury, NY, USA, 1998; ISBN 978-1-56396-774-0. 
90. Wood, J.; Southall, B.; Tollit, D. PGEE Offshore 3-D Seismic Survey Project EIR—Marine Mammal. Technical Report; SMRU Ltd.: Fife, Scotland, UK, 2012.

91. National Marine Fisheries Service. Taking and importing marine mammals; Taking marine mammals incidental to geophysical surveys related to oil and gas activities in the Gulf of Mexico. Fed. Reg. 2021, 86, 5322-5450.

92. Finneran, J.J.; Jenkins, A.K. Criteria and Thresholds for U.S. Navy Acoustic and Explosive Effects Analysis; Space and Naval Warfare Systems Center Pacific: San Diego, CA, USA, 2012.

93. Finneran, J.J.; Schlundt, C.E. Subjective loudness level measurements and equal loudness contours in a bottlenose dolphin (Tursiops truncatus). J. Acoust. Soc. Am. 2011, 130, 3124-3136. [CrossRef]

94. Feller, W. An Introduction to Probability Theory and Its Applications, 3rd ed.; John Wiley \& Sons, Inc.: New York, NY, USA, 1968; Volume 1.

95. Marine Mammal Commission. Comments and Recommendations from the U.S. Marine Mammal. Commission on National Marine Fisheries Service's Proposed Issuance of Regulations to the U.S. Navy to Take Marine Mammals Incidental to Conducting Training, Testing, and Routine Military Operations that Use Surveillance Towed Array Sensor System Low Frequency Active Sonar; Marine Mammal Commission: Bethesda, MD, USA, 2019. Available online: https:/ /www.mmc.gov/wp-content/uploads/19-04-01-HarrisonNavy-SURTASS-LFA-PR.pdf (accessed on 20 March 2021).

96. Finneran, J.J. Auditory Weighting Functions and TTS/PTS Exposure Functions for Marine Mammals Exposed to Underwater Noise; Space and Naval Warfare Systems Center Pacific: San Diego, CA, USA, 2016.

97. National Marine Fisheries Service. Technical Guidance for Assessing the Effects of Anthropogenic Sound on Marine Mammal. Hearing: Underwater Acoustic Thresholds for Onset of Permanent and Temporary Threshold Shifts; National Oceanic and Atmospheric Administration: Silver Spring, MD, USA, 2016; p. 178.

98. National Marine Fisheries Service. 2018 Revision to: Technical Guidance for Assessing the Effects of Anthropogenic Sound on Marine Mammal. Hearing (Version 2.0): Underwater Thresholds for Onset of Permanent and Temporary Threshold Shifts; National Oceanic and Atmospheric Administration: Silver Spring, MD, USA, 2018; p. 167. Available online: https://www.fisheries.noaa.gov/national/ marinemammal-protection/marine-mammal-acoustic-technical-guidance (accessed on 29 January 2021).

99. Southall, B.L.; Finneran, J.J.; Reichmuth, C.; Nachtigall, P.E.; Ketten, D.R.; Bowles, A.E.; Ellison, W.T.; Nowacek, D.P.; Tyack, P.L. Marine mammal noise exposure criteria: Updated scientific recommendations for residual hearing effects. Aquat. Mamm. 2019, 45, 125-232. [CrossRef]

100. U.S. Navy. Criteria and Thresholds for U.S. Navy Acoustic and Explosive Effects Analysis (Phase III); SSC Pacific: San Diego, CA, USA, 2017.

101. Ellison, W.T.; Southall, B.L.; Clark, C.W.; Frankel, A.S. A new context-based approach to assess marine mammal behavioral responses to anthropogenic sounds. Conserv. Biol. 2012, 26, 21-28. [CrossRef]

102. National Marine Fisheries Service. Manual for Optional USER SPREADSHEET TOOL (Version 2.2, December) for 2018 Revision to: Technical Guidance for Assessing the Effects of Anthropogenic Sound on Marine Mammal. Hearing (Version 2.0): Underwater Thresholds for Onset of Permanent and Temporary Threshold Shifts; National Oceanic and Atmospheric Administration: Silver Spring, MD, USA, 2020. Available online: https:/ / media.fisheries.noaa.gov/2020-12/User_Manual\%20_DEC_2020_508.pdf?null (accessed on 13 February 2021).

103. Sivle, L.D.; Kvadsheim, P.H.; Ainslie, M.A. Potential for population-level disturbance by active sonar in herring. ICES J. Mar. Sci. 2015, 72, 558-567. [CrossRef]

104. Marine Mammal Commission. Comments and Recommendations from the U.S. Marine Mammal. Commission on National Marine Fisheries Service's Proposed Issuance of the Technical Guidance for Assessing the Effects of Anthropogenic Sound on Marine Mammal. Hearing: Underwater Acoustic Thresholds for Onset of Permanent and Temporary Threshold Shifts; Marine Mammal Commission: Bethesda, MD, USA, 2017. Available online: https:/ / www.mmc.gov/wp-content/uploads/17-07-11-Bettridge-NMFS-Technical-Guidance.pdf (accessed on 20 March 2021).

105. Marine Mammal Commission. Comments and Recommendations from the U.S. Marine Mammal. Commission on National Marine Fisheries Service's Proposed Issuance of an Incidental Harassment Authorization to Vineyard Wind, LLC, to Take Marine Mammals Incidental to Construction of Commercial Wind Energy Turbines and Associated Facilities off Massachusetts; Marine Mammal Commission: Bethesda, MD, USA, 2019. Available online: https:/ /www.mmc.gov/wp-content/uploads/19-06-03-Harrison-NMFS-VineyardWind-wind-farm-construction-IHA.pdf (accessed on 20 March 2021).

106. Marine Mammal Commission. Comments and Recommendations from the U.S. Marine Mammal. Commission on National Marine Fisheries Service's Proposed Issuance of an Incidental Harassment Authorization to Chesapeake Tunnel Joint Venture to take marine mammals incidental to conducting construction activities for the Parallel Thimble Shoal Tunnel Bridge. Project in Virginia; Marine Mammal Commission: Bethesda, MD, USA, 2019. Available online: https://www.mmc.gov/wp-content/uploads/19-12-26-HarrisonChesapeake-Tunnel-Joint-Venture-IHA.pdf (accessed on 20 March 2021).

107. Marine Mammal Commission. Comments and Recommendations from the U.S. Marine Mammal. Commission on National Marine Fisheries Service's Proposed Issuance of an Incidental Harassment Authorization to Virginia Electric and Power Company d/b/a/ Dominion Energy Virginia to Take Marine Mammals Incidental to Construction of Wind Energy Turbines off the Coast. of Virginia; Marine Mammal Commission: Bethesda, MD, USA, 2020. Available online: https://www.mmc.gov/wp-content/uploads/20-04-15-HarrisonDominion-wind-energy-construction-IHA.pdf (accessed on 20 March 2021). 
108. Marine Mammal Commission. Comments and Recommendations from the U.S. Marine Mammal. Commission on National Marine Fisheries Service's Proposed Incidental Harassment Authorization Renewal to Port. of Kalama to Renew. its Authorization to Take Marine Mammals Incidental to Construction of the Kalama Manufacturing and Marine Export Facility on the Columbia River in Washington; Marine Mammal Commission: Bethesda, MD, USA, 2020. Available online: https://www.mmc.gov/wp-content/uploads/20-1105-Harrison-Port-of-Kalama-IHA-renewal.pdf (accessed on 20 March 2021).

109. Frankel, A.S.; Ellison, W.T.; Buchanan, J. Application of the Acoustic Integration Model (AIM) to predict and minimize environmental impacts. In Proceedings of the Oceans '02 MTS/IEEE, Biloxi, MI, USA, 29-31 October 2002; pp. 1438-1443.

110. Houser, D.S. A method for modeling marine mammal movement and behavior for environmental impact assessment. IEEE J. Ocean. Eng. 2006, 31, 76-81. [CrossRef]

111. U.S. Navy. Determination of Acoustic Effects on Marine Mammals and Sea Turtles for the Hawaii-Southern California Training and Testing Environmental Impact Statement/Overseas Environmental Impact Statement; Naval Undersea Warfare Center Division: Newport, RI, USA, 2012.

112. Ellison, W.; Racca, R.; Clark, C.; Streever, B.; Frankel, A.; Fleishman, E.; Angliss, R.; Berger, J.; Ketten, D.; Guerra, M.; et al. Modeling the aggregated exposure and responses of bowhead whales Balaena mysticetus to multiple sources of anthropogenic underwater sound. Endang. Species. Res. 2016, 30, 95-108. [CrossRef]

113. Blackstock, S.A.; Fayton, J.O.; Hulton, P.H.; Moll, T.E.; Jenkins, K.K.; Kotecki, S.; Henderson, E.; Rider, S.; Martin, C.; Bowman, V. Quantifying Acoustic Impacts on Marine Mammals and Sea Turtles: Methods and Analytical Approach for Phase III Training and Testing; Naval Undersea Warfare Center Division: Newport, RI, USA, 2017.

114. Denes, S.L.; Zeddies, D.G.; Weirathmueller, M.J. Turbine Foundation and Cable Installation at South. Fork Wind Farm: Underwater Acoustic Modeling of Construction Noise; JASCO Applied Sciences: Silver Spring, MD, USA, 2018.

115. Matthews, M.-N.R.; Ireland, D.S.; Zeddies, D.G.; Brune, R.H.; Pyć, C.D. A modeling comparison of the potential effects on marine mammals from sounds produced by marine vibroseis and air gun seismic sources. J. Mar. Sci. Eng. 2021, 9, 12. [CrossRef]

116. Shaffer, S.A.; Costa, D.P. A database for the study of marine mammal behavior: Gap analysis, data standardization, and future directions. IEEE J. Ocean. Eng. 2006, 31, 82-86. [CrossRef]

117. Frankel, A.S.; Vigness-Raposa, K.; Giard, J.; White, A.; Ellison, W.T. Exposures v. individuals: Effects of varying movement patterns and animal behavior on long-term animat model exposure predictions. Proc. Meet. Acoust. 2016, 27, 10038. [CrossRef]

118. Borcuk, J.R.; Mitchell, G.H.; Watwood, S.L.; Moll, T.E.; Oliveira, E.M.; Robinson, E.R. Dive Distribution and Group Size Parameters for Marine Species Occurring in the U.S. Navy's Atlantic and Hawaii-Southern California Training and Testing Study Areas; NUWC-NPT Technical Report; Naval Undersea Warfare Center Division: Newport, RI, USA, 2017.

119. National Marine Fisheries Service. Taking and importing marine mammals; taking marine mammals incidental to Southwest Fisheries Science Center Fisheries Research. Fed. Reg. 2020, 85, 53606-53640.

120. National Marine Fisheries Service. Takes of marine mammals incidental to specified activities; taking marine mammals incidental to site characterization surveys off the coast of Massachusetts. Fed. Reg. 2021, 86, 11930-11947.

121. U.S. Fish and Wildlife Service. Marine mammals; incidental take during specified activities; proposed incidental harassment authorization for Pacific walruses and polar bears in Alaska and associated Federal waters. Fed. Reg. 2017, 82, $25304-25322$.

122. U.S. Fish and Wildlife Service. Marine mammals; incidental take during specified activities: Cook Inlet, Alaska. Fed. Reg. 2019, 84, 10224-10251.

123. U.S. Fish and Wildlife Service. Marine Mammals; Incidental Take During Specified Activities; Proposed Incidental Harassment Authorizations for Northern Sea Otters in Southeast Alaska. Fed. Reg. 2019, 84, 32932-32945.

124. Marine Mammal Commission. Comments and Recommendations from the U.S. Marine Mammal. Commission on U.S. Navy's Draft Supplemental Environmental Impact Statement/Overseas Environmental Impact Statement for Training Activities Conducted within the Temporary Maritime Activities Area in the Gulf of Alaska; Marine Mammal Commission: Bethesda, MD, USA, 2021. Available online: https://www.mmc.gov/wp-content/uploads/21-01-04-Naval-Facilities-Engineering-Command-NorthwestGOA-Phase-III-DSEIS.pdf (accessed on 20 March 2021).

125. Tyack, P.L.; Thomas, L. Using dose-response functions to improve calculations of the impact of anthropogenic noise. Aquat. Conser. Mar. Freshwater Ecosys. 2019, 29, 242-253. [CrossRef]

126. Danil, K.; St. Leger, J.A. Seabird and dolphin mortality associated with underwater detonation exercises. Mar. Technol. Soc. J. 2011, 45, 89-95. [CrossRef]

127. National Marine Fisheries Service. Takes of marine mammals incidental to specified activities; taking marine mammals incidental to Washington State Department of Transportation Purdy Bridge Rehabilitation Project, Pierce County, WA. Fed. Reg. 2020, 85, 81886-81904.

128. National Marine Fisheries Service. Takes of marine mammals incidental to specified activities; taking marine mammals incidental to Gastineau Channel Historical Society Sentinel Island moorage float project, Juneau, Alaska. Fed. Reg. 2020, 85, 18196-18213.

129. Marine Mammal Commission. Comments and Recommendations from the U.S. Marine Mammal. Commission on National Marine Fisheries Service's Proposed Issuance for an Incidental Harassment Authorization to Lamont-Doherty Earth Observatory to Take Marine Mammals Incidental to Conducting Two Marine Geophysical Surveys in the North. Pacific Ocean; Marine Mammal Commission: Bethesda, MD, USA, 2018. Available online: https:/ / www.mmc.gov/wp-content/uploads/18-07-20-Harrison-LDEO-HI-IHA pdf (accessed on 20 March 2021). 
130. Marine Mammal Commission. Comments and Recommendations from the U.S. Marine Mammal. Commission on National Marine Fisheries Service's Proposed Issuance of Regulations to U.S. Navy to take Marine Mammals Incidental to Conducting Training and Testing Activities in the Hawaii-Southern California Training and Testing Study Area; Marine Mammal Commission: Bethesda, MD, USA, 2018. Available online: https:/ / www.mmc.gov/wp-content/uploads/18-07-13-Harrison-Navy-HSTT-PR-Phase-III.pdf (accessed on 20 March 2021).

131. Marine Mammal Commission. Comments and Recommendations from the U.S. Marine Mammal. Commission on U.S. Navy's Draft Supplemental Environmental Impact Statement/Overseas Environmental Impact Statement to Conduct Training and Research, Development, Testing, and Evaluation Activities within the Northwest. Training and Testing Study Area; Marine Mammal Commission: Bethesda, MD, USA, 2019. Available online: https://www.mmc.gov/wp-content/uploads/19-04-15-Naval-Facilities-Engineering-CommandNorthwest-NWTT-DSEIS.pdf (accessed on 20 March 2021).

132. Marine Mammal Commission. Comments and Recommendations from the U.S. Marine Mammal. Commission on National Marine Fisheries Service's Proposed Issuance of an Incidental Harassment Authorization to U.S. Army Corps of Engineers, Portland District to Take Marine Mammals Incidental to Replacing Dike Markers in the Columbia River. 11 September 2019; Marine Mammal Commission: Bethesda, MD, USA, 2019. Available online: https: / /www.mmc.gov/wp-content/uploads/19-09-11-Harrision-USACE-CRmarker-IHA.pdf (accessed on 20 March 2021).

133. Marine Mammal Commission. Comments and Recommendations from the U.S. Marine Mammal. Commission on National Marine Fisheries Service's Proposed Issuance of an Incidental Harassment Authorization to Jordan Cove Energy Project, LP to Take Marine Mammals Incidental to Construction of the Jordan Cove Liquefied Natural Gas. (LNG) Facility and Ancillary Activities in Coos Bay, Oregon; Marine Mammal Commission: Bethesda, MD, USA, 2019. Available online: https:/ /www.mmc.gov/wp-content/uploads/19-12-18 -Harrison-NMFS-proposed-IHA-Jordan-Cove-LNG_corrected.pdf (accessed on 20 March 2021).

134. Ketten, D.R. Structure and function in whale ears. Bioacoustics 1997, 8, 103-135. [CrossRef]

135. Parks, S.E.; Ketten, D.R.; O'Malley, J.T.; Arruda, J. Anatomical predictions of hearing in the North Atlantic right whale. Anat. Rec. 2007, 290, 734-744. [CrossRef]

136. Mooney, T.A.; Yamato, M.; Branstetter, B.K. Chapter Four-Hearing in Cetaceans: From Natural History to Experimental Biology. In Advances in Marine Biology; Lesser, M., Ed.; Academic Press: New York, NY, USA, 2012; Volume 63, pp. 197-246.

137. Cranford, T.W.; Krysl, P. Fin whale sound reception mechanisms: Skull vibration enables low-frequency hearing. PLoS ONE 2015, 10, e0116222. [CrossRef]

138. Tubelli, A.; Zosuls, A.; Ketten, D.; Mountain, D.C. Prediction of a mysticete audiogram via finite element analysis of the middle ear. In The Effects of Noise on Aquatic Life II; Advances in Experimental Medicine and Biology; Springer: New York, NY, USA, 2015; Volume 875, pp. 57-59.

139. Tubelli, A.A.; Zosuls, A.; Ketten, D.R.; Mountain, D.C. A model and experimental approach to the middle ear transfer function related to hearing in the humpback whale (Megaptera novaeangliae). J. Acoust. Soc. Am. 2018, 144, 525-535. [CrossRef] [PubMed]

140. Cook, M.L.H.; Varela, R.A.; Goldstein, J.D.; McCulloch, S.D.; Bossart, G.D.; Finneran, J.J.; Houser, D.; Mann, D.A. Beaked whale auditory evoked potential hearing measurements. J. Comp. Physiol. A 2006, 192, 489-495. [CrossRef] [PubMed]

141. Finneran, J.J.; Houser, D.S.; Mase-Guthrie, B.; Ewing, R.Y.; Lingenfelser, R.G. Auditory evoked potentials in a stranded Gervais' beaked whale (Mesoplodon europaeus). J. Acoust. Soc. Am. 2009, 126, 484-490. [CrossRef]

142. Pacini, A.F.; Nachtigall, P.E.; Quintos, C.T.; Schofield, T.D.; Look, D.A.; Levine, G.A.; Turner, J.P. Audiogram of a stranded Blainville's beaked whale (Mesoplodon densirostris) measured using auditory evoked potentials. J. Exp. Biol. 2011, 214, $2409-2415$. [CrossRef] [PubMed]

143. Ward, W.D.; Glorig, A.; Sklar, D.L. Temporary threshold shift from octave-band noise: Applications to damage-risk criteria. J. Acoust. Soc. Am. 1959, 31, 522-528. [CrossRef]

144. Luz, G.A.; Hodge, D.C. Recovery from impulse-noise induced TTS in monkeys and men: A descriptive model. J. Acoust. Soc. Am. 1971, 49, 1770-1777. [CrossRef] [PubMed]

145. Sulkowski, W.J.; Lipowczan, A. Impulse noise-induced hearing loss in drop forge operators and the energy concept. Noise Control. Eng. 1982, 18, 24-29. [CrossRef]

146. Hamernik, R.P.; Patterson, J.H.; Salvi, R.J. The Effect of impulse intensity and the number of impulses on hearing and cochlear pathology in the chinchilla. J. Acoust. Soc. Am. 1987, 81, 1118-1129. [CrossRef]

147. Dunn, D.E.; Davis, R.R.; Merry, C.J.; Franks, J.R. Hearing loss in the chinchilla from impact and continuous noise exposure. J. Acoust. Soc. Am. 1991, 90, 1979-1985. [CrossRef]

148. Hamernik, R.P.; Qiu, W. Energy-independent factors influencing noise-induced hearing loss in the chinchilla model. J. Acoust. Soc. Am. 2001, 110, 3163-3168. [CrossRef]

149. Guan, S.; Miner, R. Underwater noise characterization of down-the-hole pile driving activities off Biorka Island, Alaska. Mar. Pollut. Bull. 2020, 160, 111664. [CrossRef]

150. Qiu, W.; Davis, B.; Hamernik, R.P. Hearing loss from interrupted, intermittent, and time varying Gaussian noise exposures: The applicability of the equal energy hypothesis. J. Acoust. Soc. Am. 2007, 121, 1613-1620. [CrossRef]

151. Hamernik, R.P.; Qiu, W.; Davis, B. Hearing loss from interrupted, intermittent, and time Varying non-Gaussian noise exposure: The applicability of the equal energy hypothesis. J. Acoust. Soc. Am. 2007, 122, 2245-2254. [CrossRef]

152. Zhao, Y.; Qiu, W.; Zeng, L.; Chen, S.; Cheng, X.; Davis, R.I.; Hamernik, R.P. Application of the kurtosis statistic to the evaluation of the risk of hearing loss in workers exposed to high-level complex noise. Ear Hear. 2010, 31, 527-532. [CrossRef] 
153. Qiu, W.; Hamernik, R.P.; Davis, R.I. The value of a kurtosis metric in estimating the hazard to hearing of complex industrial noise exposures. J. Acoust. Soc. Am. 2013, 133, 2856-2866. [CrossRef] [PubMed]

154. Xie, H.; Qiu, W.; Heyer, N.J.; Zhang, M.; Zhang, P.; Zhao, Y.; Hamernik, R.P. The use of the kurtosis-adjusted cumulative noise exposure metric in evaluating the hearing loss risk for complex noise. Ear Hear. 2016, 37, 312-323. [CrossRef] [PubMed]

155. Moretti, D.; Thomas, L.; Marques, T.; Harwood, J.; Dilley, A.; Neales, B.; Shaffer, J.; McCarthy, E.; New, L.; Jarvis, S.; et al. A risk function for behavioral disruption of Blainville's beaked whales (Mesoplodon densirostris) from mid-frequency active sonar. PLoS ONE 2014, 9, e85064. [CrossRef]

156. Miller, P.J.O.; Antunes, R.N.; Wensveen, P.J.; Samarra, F.I.P.; Catarina Alves, A.; Tyack, P.L.; Kvadsheim, P.H.; Kleivane, L.; Lam, F.-P.A.; Ainslie, M.A.; et al. Dose-response relationships for the onset of avoidance of sonar by free-ranging killer whales. J. Acoust. Soc. Am. 2014, 135, 975-993. [CrossRef] [PubMed]

157. Richardson, W.J.; Miller, G.W.; Greene, C.R. Displacement of migrating bowhead whales by sounds from seismic surveys in shallow waters of the Beaufort Sea. J. Acoust. Soc. Am. 1999, 106, 2281. [CrossRef]

158. Miller, G.W.; Moulton, V.D.; Davis, R.A.; Holst, M.; Millman, P.; MacGillivray, A.; Hannay, D. Monitoring seismic effects on marine mammals—southeastern Beaufort Sea, 2001-2002. In Offshore Oil and Gas Environmental Effects Monitoring: Approaches and Technologies; Armsworthy, S.L., Cranford, P.J., Lee, K., Eds.; Battelle Press: Columbus, OH, USA, 2005; pp. 511-542.

159. Miller, P.J.O.; Johnson, M.P.; Madsen, P.T.; Biassoni, N.; Quero, M.; Tyack, P.L. Using at-sea experiments to study the effects of airguns on the foraging behavior of sperm whales in the Gulf of Mexico. Deep Sea Res. Part. I 2009, 56, 1168-1181. [CrossRef]

160. Blackwell, S.B.; Nations, C.S.; McDonald, T.L.; Thode, A.M.; Mathias, D.; Kim, K.H.; Greene, C.R., Jr.; Macrander, A.M. Effects of airgun sounds on bowhead whale calling rates: Evidence for two behavioral thresholds. PLoS ONE 2015, 10, e0125720. [CrossRef] [PubMed]

161. Graham, I.M.; Merchant, N.D.; Farcas, A.; Barton, T.R.; Cheney, B.; Bono, S.; Thompson, P.M. Harbour porpoise responses to pile-driving diminish over time. R. Soc. Open Sci. 2019, 6. [CrossRef]

162. Russell, D.J.F.; Hastie, G.D.; Thompson, D.; Janik, V.M.; Hammond, P.S.; Scott-Hayward, L.A.S.; Matthiopoulos, J.; Jones, E.L.; McConnell, B.J. Avoidance of wind farms by harbour seals is limited to pile driving activities. J. Appl. Ecol. 2016, 53, 1642-1652. [CrossRef]

163. Brandt, M.J.; Dragon, A.-C.; Diederichs, A.; Bellmann, M.A.; Wahl, V.; Piper, W.; Nabe-Nielsen, J.; Nehls, G. Disturbance of harbour porpoises during construction of the first seven offshore wind farms in Germany. Mar. Ecol. Prog. Ser. 2018, 596, 213-232. [CrossRef]

164. New, L.F.; Moretti, D.J.; Hooker, S.K.; Costa, D.P.; Simmons, S.E. Using energetic models to investigate the survival and reproduction of beaked whales (family Ziphiidae). PLoS ONE 2013, 8, e68725. [CrossRef] [PubMed]

165. Villegas-Amtmann, S.; Schwarz, L.K.; Sumich, J.L.; Costa, D.P. A bioenergetics model to evaluate demographic consequences of disturbance in marine mammals applied to gray whales. Ecosphere 2015, 6, 1-19. [CrossRef]

166. Schwarz, L.K.; McHuron, E.; Mangel, M.; Wells, R.S.; Costa, D.P. Stochastic dynamic programming: An approach for modelling the population consequences of disturbance due to lost foraging opportunities. Proc. Meet. Acoust. 2016, 27, 040004. [CrossRef]

167. McHuron, E.A.; Peterson, S.H.; Hückstädt, L.A.; Melin, S.R.; Harris, J.D.; Costa, D.P. The energetic consequences of behavioral variation in a marine carnivore. Ecol. Evol. 2018, 8, 4340-4351. [CrossRef]

168. Pirotta, E.; Booth, C.G.; Costa, D.P.; Fleishman, E.; Kraus, S.D.; Lusseau, D.; Moretti, D.; New, L.F.; Schick, R.S.; Schwarz, L.K.; et al. Understanding the population consequences of disturbance. Ecol. Evol. 2018, 8, 9934-9946. [CrossRef]

169. Wilson, L.J.; Harwood, J.; Booth, C.G.; Joy, R.; Harris, C.M. A decision framework to identify populations that are most vulnerable to the population level effects of disturbance. Conserv. Sci. Pract. 2020, 2, e149. [CrossRef]

170. Pirotta, E.; Booth, C.G.; Cade, D.E.; Calambokidis, J.; Costa, D.P.; Fahlbusch, J.A.; Friedlaender, A.S.; Goldbogen, J.A.; Harwood, J.; Hazen, E.L.; et al. Context-dependent variability in the predicted daily energetic costs of disturbance for blue whales. Conserv. Physiol. 2021, 9. [CrossRef]

171. Booth, C.G.; Sinclair, R.R.; Harwood, J. Methods for monitoring for the population consequences of disturbance in marine mammals: A review. Front. Mar. Sci. 2020, 7. [CrossRef]

172. Reichmuth, C. Psychophysical Studies of Auditory Masking in Marine Mammals: Key Concepts and New Directions. In The Effects of Noise on Aquatic Life; Popper, A.N., Hawkins, A., Eds.; Advances in Experimental Medicine and Biology; Springer: New York, NY, USA, 2012; Volume 730, pp. 23-27.

173. Erbe, C.; Reichmuth, C.; Cunningham, K.; Lucke, K.; Dooling, R. Communication masking in marine mammals: A review and research strategy. Mar. Pollut. Bull. 2016, 103, 15-38. [CrossRef]

174. Clark, C.; Ellison, W.; Southall, B.; Hatch, L.; Van Parijs, S.; Frankel, A.; Ponirakis, D. Acoustic masking in marine ecosystems: Intuitions, analysis, and implication. Mar. Ecol. Prog. Ser. 2009, 395, 201-222. [CrossRef]

175. Guan, S.; Southall, B.L.; Barlow, J.; Vignola, J.F.; Judge, J.A.; Turo, D. Inter-ping sound field from a simulated mid-frequency active sonar, and its implication to marine mammal tonal masking. Proc. Meet. Acoust. 2016, 27, 070023. [CrossRef]

176. Pine, M.K.; Hannay, D.E.; Insley, S.J.; Halliday, W.D.; Juanes, F. Assessing vessel slowdown for reducing auditory masking for marine mammals and fish of the western Canadian Arctic. Mar. Pollut. Bull. 2018, 135, 290-302. [CrossRef] [PubMed]

177. Pine, M.K.; Nikolich, K.; Martin, B.; Morris, C.; Juanes, F. Assessing auditory masking for management of underwater anthropogenic noise. J. Acoust. Soc. Am. 2020, 147, 3408-3417. [CrossRef] [PubMed] 
178. Miller, P.J.O.; Biassoni, N.; Samuels, A.; Tyack, P.L. Whale songs lengthen in response to sonar. Nature 2000, 405, 903. [CrossRef] [PubMed]

179. Foote, A.D.; Osborne, R.W.; Hoelzel, A.R. Whale-call response to masking boat noise. Nature 2004, 428, 910. [CrossRef]

180. Di Iorio, L.; Clark, C.W. Exposure to seismic survey alters blue whale acoustic communication. Biol. Lett. 2010, 6, 51-54. [CrossRef] [PubMed]

181. Thode, A.M.; Blackwell, S.B.; Conrad, A.S.; Kim, K.H.; Marques, T.; Thomas, L.; Oedekoven, C.S.; Harris, D.; Bröker, K. Roaring and repetition: How bowhead whales adjust their call density and source level (Lombard effect) in the presence of natural and seismic airgun survey noise. J. Acoust. Soc. Am. 2020, 147, 2061-2080. [CrossRef]

182. Parks, S.E.; Clark, C.W.; Tyack, P.L. Short- and long-term changes in right whale calling behavior: The potential effects of noise on acoustic communication. J. Acoust. Soc. Am. 2007, 122, 3725-3731. [CrossRef]

183. Scheifele, P.M.; Andrew, S.; Cooper, R.A.; Darre, M.; Musiek, F.E.; Max, L. Indication of a Lombard vocal response in the St. Lawrence River beluga. J. Acoust. Soc. Am. 2005, 117, 1486-1492. [CrossRef]

184. Holt, M.M.; Noren, D.P.; Veirs, V.; Emmons, C.K.; Veirs, S. Speaking up: Killer whales (Orcinus orca) increase their call amplitude in response to vessel noise. J. Acoust. Soc. Am. 2009, 125, EL27-EL32. [CrossRef] [PubMed]

185. Parks, S.E.; Johnson, M.; Nowacek, D.; Tyack, P.L. Individual right whales call louder in increased environmental noise. Biol. Lett. 2011, 7, 33-35. [CrossRef] [PubMed]

186. Dunlop, R.A.; Cato, D.H.; Noad, M.J. Evidence of a Lombard response in migrating humpback whales (Megaptera novaeangliae). J. Acoust. Soc. Am. 2014, 136, 430-437. [CrossRef] [PubMed]

187. Fournet, M.E.H.; Matthews, L.P.; Gabriele, C.M.; Haver, S.; Mellinger, D.K.; Klinck, H. Humpback whales Megaptera novaeangliae alter calling behavior in response to natural sounds and vessel noise. Mar. Ecol. Prog. Ser. 2018, 607, 251-268. [CrossRef]

188. Helble, T.A.; Guazzo, R.A.; Martin, C.R.; Durbach, I.N.; Alongi, G.C.; Martin, S.W.; Boyle, J.K.; Henderson, E.E. Lombard effect: Minke whale boing call source levels vary with natural variations in ocean noise. J. Acoust. Soc. Am. 2020, 147, 698-712. [CrossRef]

189. Guazzo, R.A.; Helble, T.A.; Alongi, G.C.; Durbach, I.N.; Martin, C.R.; Martin, S.W.; Henderson, E.E. The Lombard effect in singing humpback whales: Source levels increase as ambient ocean noise levels increase. J. Acoust. Soc. Am. 2020, 148, 542-555. [CrossRef]

190. Brumm, H.; Zollinger, S.A. The evolution of the Lombard effect: 100 years of psychoacoustic research. Behaviour 2011, 148, 1173-1198. [CrossRef]

191. Noren, D.P.; Holt, M.M.; Dunkin, R.C.; Williams, T.M. The metabolic cost of communicative sound production in bottlenose dolphins (Tursiops truncatus). J. Exp. Biol. 2013, 216, 1624-1629. [CrossRef]

192. Holt, M.M.; Noren, D.P.; Dunkin, R.C.; Williams, T.M. Vocal performance affects metabolic rate in dolphins: Implications for animals communicating in noisy environments. J. Exp. Biol. 2015, 218, 1647-1654. [CrossRef]

193. Noren, D.P.; Holt, M.M.; Dunkin, R.C.; Williams, T.M. The metabolic cost of whistling is low but measurable in dolphins. J. Exp. Biol. 2020, 223. [CrossRef] [PubMed]

194. Ising, H.; Kruppa, B. Health effects caused by noise: Evidence in the literature from the past 25 years. Noise Health 2004, 6, 5-13. [PubMed]

195. Skogstad, M.; Johannessen, H.A.; Tynes, T.; Mehlum, I.S.; Nordby, K.-C.; Lie, A. Systematic review of the cardiovascular effects of occupational noise. Occup. Med. 2016, 66, 10-16. [CrossRef] [PubMed]

196. Park, T.; Kim, M.; Jang, C.; Choung, T.; Sim, K.-A.; Seo, D.; Chang, S.I. The public health impact of road-traffic noise in a highly-populated city, Republic of Korea: Annoyance and sleep disturbance. Sustainability 2018, 10, 2947. [CrossRef]

197. Bolm-Audorff, U.; Hegewald, J.; Pretzsch, A.; Freiberg, A.; Nienhaus, A.; Seidler, A. Occupational noise and hypertension risk: A systematic review and meta-analysis. Int. J. Environ. Res. Public Health 2020, 17, 6281. [CrossRef]

198. Shin, S.; Bai, L.; Oiamo, T.H.; Burnett, R.T.; Weichenthal, S.; Jerrett, M.; Kwong, J.C.; Goldberg, M.S.; Copes, R.; Kopp, A.; et al. Association between road traffic noise and incidence of diabetes mellitus and hypertension in Toronto, Canada: A population-based cohort study. J. Am. Heart Ass. 2020, 9, e013021. [CrossRef]

199. Liu, J.; Zhu, B.; Xia, Q.; Ji, X.; Pan, L.; Bao, Y.; Lin, Y.; Zhang, R. The effects of occupational noise exposure on the cardiovascular system: A review. J. Public Health Emerg. 2020, 4. [CrossRef]

200. Wright, A.J.; Soto, N.A.; Baldwin, A.L.; Bateson, M.; Beale, C.M.; Clark, C.; Deak, T.; Edwards, E.F.; Fernández, A.; Godinho, A.; et al. Do marine mammals experience stress related to anthropogenic noise? Int. J. Comp. Psychol. 2007, 20, $274-316$.

201. Kellar, N.M.; Catelani, K.N.; Robbins, M.N.; Trego, M.L.; Allen, C.D.; Danil, K.; Chivers, S.J. Blubber cortisol: A potential tool for assessing stress response in free-ranging dolphins without effects due to sampling. PLoS ONE 2015, 10, e0115257. [CrossRef]

202. Bechshoft, T.; Wright, A.J.; Weisser, J.J.; Teilmann, J.; Dietz, R.; Hansen, M.; Björklund, E.; Styrishave, B. Developing a new research tool for use in free-ranging cetaceans: Recovering cortisol from harbour porpoise skin. Conserv. Physiol. 2015, 3. [CrossRef]

203. Keogh, M.J.; Gastaldi, A.; Charapata, P.; Melin, S.; Fadely, B.S. Stress-related and reproductive hormones in hair from three North Pacific otariid species: Steller sea lions, California sea lions and northern fur seals. Conserv. Physiol. 2020, 8. [CrossRef]

204. Pujade Busqueta, L.; Crocker, D.E.; Champagne, C.D.; McCormley, M.C.; Deyarmin, J.S.; Houser, D.S.; Khudyakov, J.I. A blubber gene expression index for evaluating stress in marine mammals. Conserv. Physiol. 2020, 8, coaa082. [CrossRef] [PubMed]

205. Bechshoft, T.; Wright, A.J.; Styrishave, B.; Houser, D. Measuring and validating concentrations of steroid hormones in the skin of bottlenose dolphins (Tursiops truncatus). Conserv. Physiol. 2020, 8. [CrossRef] [PubMed]

206. Moore, S.E.; Reeves, R.R.; Southall, B.L.; Ragen, T.J.; Suydam, R.S.; Clark, C.W. A new framework for assessing the effects of anthropogenic sound on marine mammals in a rapidly changing Arctic. BioScience 2012, 62, 289-295. [CrossRef] 
207. National Academies of Sciences, Engineering, and Medicine. Approaches to Understanding the Cumulative Effects of Stressors on Marine Mammals; National Academies Press: Washington, DC, USA, 2017; ISBN 978-0-309-44048-6.

208. Faulkner, R.C.; Farcas, A.; Merchant, N.D. Guiding principles for assessing the impact of underwater noise. J. Appl. Ecol. 2018, 55, 2531-2536. [CrossRef]

209. Pirotta, E.; Mangel, M.; Costa, D.P.; Goldbogen, J.; Harwood, J.; Hin, V.; Irvine, L.M.; Mate, B.R.; McHuron, E.A.; Palacios, D.M.; et al. Anthropogenic disturbance in a changing environment: Modelling lifetime reproductive success to predict the consequences of multiple stressors on a migratory population. Oikos 2019, 128, 1340-1357. [CrossRef]

210. Houser, D.S.; Finneran, J.J.; Ridgway, S.H. Research with Navy marine mammals benefits animal care, conservation and biology. Int. J. Comp. Psychol. 2010, 23, 249-268.

211. Fetherston, T. Environment in a (high-tech) box: Navy model simulates undersea sound fields \& marine mammal locations to plan training \& testing activities. Currents 2011, 42-43. 